\title{
Technical Note: Quantitative long-term measurements of VOC concentrations by PTR-MS - measurement, calibration, and volume mixing ratio calculation methods
}

\author{
R. Taipale ${ }^{1}$, T. M. Ruuskanen ${ }^{1}$, J. Rinne ${ }^{1}$, M. K. Kajos ${ }^{1}$, H. Hakola ${ }^{2}$, T. Pohja ${ }^{3}$, and M. Kulmala ${ }^{1}$ \\ ${ }^{1}$ University of Helsinki, Department of Physics, P.O. Box 68, 00014 University of Helsinki, Finland \\ ${ }^{2}$ Finnish Meteorological Institute, Air Quality Research, P.O. Box 503, 00101 Helsinki, Finland \\ ${ }^{3}$ University of Helsinki, Hyytiälä Forestry Field Station, Hyytiäläntie 124, 35500 Korkeakoski, Finland
}

Received: 13 February 2008 - Published in Atmos. Chem. Phys. Discuss.: 23 May 2008

Revised: 30 September 2008 - Accepted: 1 October 2008 - Published: 19 November 2008

\begin{abstract}
Proton transfer reaction mass spectrometry (PTRMS) is a technique for online measurements of atmospheric concentrations, or volume mixing ratios, of volatile organic compounds (VOCs). This paper gives a detailed description of our measurement, calibration, and volume mixing ratio calculation methods, which have been designed for longterm stand-alone field measurements by PTR-MS. The PTRMS instrument has to be calibrated regularly with a gas standard to ensure the accuracy needed in atmospheric VOC measurements. We introduce a novel method for determining an instrument specific relative transmission curve using information obtained from a calibration. This curve enables consistent mixing ratio calculation for VOCs not present in a calibration gas standard. Our method proved to be practical, systematic, and sensitive enough to capture changes in the transmission over time. We also propose a new approach to considering the abundance of $\mathrm{H}_{3} \mathrm{O}^{+} \mathrm{H}_{2} \mathrm{O}$ ions in mixing ratio calculation. The approach takes into account the difference in the transmission efficiencies for $\mathrm{H}_{3} \mathrm{O}^{+}$and $\mathrm{H}_{3} \mathrm{O}^{+} \mathrm{H}_{2} \mathrm{O}$ ions. To illustrate the functionality of our measurement, calibration, and calculation methods, we present a one-month period of ambient mixing ratio data measured in a boreal forest ecosystem at the SMEAR II station in southern Finland. During the measurement period 27 March26 April 2007, the hourly averages of the mixing ratios were $0.051-0.57 \mathrm{ppbv}$ for formaldehyde, $0.19-3.1 \mathrm{ppbv}$ for methanol, $0.038-0.39 \mathrm{ppbv}$ for benzene, and $0.020-1.3 \mathrm{ppbv}$
\end{abstract}

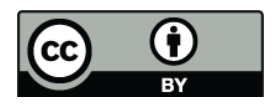

Correspondence to: R. Taipale (risto.taipale@helsinki.fi) for monoterpenes. The detection limits for the hourly averages were $0.020,0.060,0.0036$, and $0.0092 \mathrm{ppbv}$, respectively.

\section{Introduction}

Volatile organic compounds (VOCs) are emitted into the atmosphere from a wide variety of natural and anthropogenic sources. VOCs may also be formed in the atmosphere as products of the atmospheric transformations of other VOCs. Globally, biogenic VOC emissions (about $1150 \mathrm{Tg}$ (C) per year) are estimated to be approximately ten times higher than emissions due to human activity, but in urban areas anthropogenic VOCs often dominate (Piccot et al., 1992; Guenther et al., 1995). The largest VOC sources are tropical and extratropical forests, which emit especially isoprene, monoterpenes, and methanol. Also biomass burning is a large source on a global scale and leads to emissions of numerous VOCs, including aromatic hydrocarbons, nitriles, and oxygenated compounds (Andreae and Merlet, 2001).

VOCs play a significant role in tropospheric chemistry in urban, rural, and remote areas. They affect concentrations of the hydroxyl radical $(\mathrm{OH})$, the nitrate radical $\left(\mathrm{NO}_{3}\right)$, and ozone $\left(\mathrm{O}_{3}\right)$, and hence the oxidative capacity of the lower atmosphere (Atkinson and Arey, 2003). VOCs are also involved in the formation and growth of atmospheric aerosol particles (Kulmala et al., 2004; Allan et al., 2006; Tunved et al., 2006), which are an important factor in the climate system, either directly through the absorption and scattering of solar radiation, or indirectly by acting as cloud condensation

Published by Copernicus Publications on behalf of the European Geosciences Union. 
nuclei. In addition, VOCs may have an effect on the optical properties of aerosol particles (Nozière and Esteve, 2005).

Atmospheric VOC measurements are often based on gas chromatographic analyses of air samples collected on adsorbents, in canisters, or in cryostats. Such measurements are very sensitive and give highly detailed information on the atmospheric VOC composition. Due to the required sampling times, these methods are generally too slow to follow rapid changes in the VOC composition. This disadvantage can be partially overcome by using canisters, which can be filled in a few seconds. However, the acquisition and analysis of canister samples is time-consuming and labour-intensive, which limits the amount of data that can be collected in any given period.

Proton transfer reaction mass spectrometry (PTR-MS) is a novel technique for online measurements of atmospheric volume mixing ratios of VOCs (Lindinger et al., 1998a). In the PTR-MS instrument, ambient air is continuously pumped through a drift tube reactor and the VOCs in the sample are ionized in proton transfer reactions with hydronium ions $\left(\mathrm{H}_{3} \mathrm{O}^{+}\right)$. This is a soft ionization method, which often does not lead to fragmentation of the product ions, and the mass of the product ion equals the VOC mass plus one. The reagent and product ions are selected according to their masses by a quadrupole mass spectrometer and detected by a secondary electron multiplier. PTR-MS allows measurements of numerous VOCs with a high sensitivity (10-100 parts per trillion by volume (pptv)) and a fast response time (0.1-10 s). The technique does not require any sample treatment, such as drying or preseparation, and is thus suitable for oxygenated VOCs, which are difficult to detect with other methods. Since PTR-MS determines only the masses of the product ions, different VOCs with the same mass cannot be distinguished. Therefore, a lot of experimental work has been done to characterize the specificity of PTR-MS for several VOCs (e.g. de Gouw et al., 2003a; Warneke et al., 2003).

PTR-MS has been used for field and laboratory measurements since the late nineties. Over the years, it has proven to be a valuable tool in atmospheric research (for a review, see de Gouw and Warneke, 2007). For example, PTR-MS has been utilized in ambient mixing ratio measurements in urban, rural, and remote areas using aircraft-, ship-, vehicle-, or ground-based platforms (e.g. Crutzen et al., 2000; Holzinger et al., 2001; Wisthaler et al., 2002; de Gouw et al., 2003b, 2004; Karl et al., 2003b; Ammann et al., 2004; Jiang et al., 2005; Warneke et al., 2006), in plant chamber experiments to study leaf or shoot scale emissions of VOCs (e.g. Fall et al., 1999; Karl et al., 2002a; Hayward et al., 2004), in micrometeorological ecosystem scale flux measurements with eddy covariance techniques (e.g. Karl et al., 2001, 2002b; Rinne et al., 2001; Warneke et al., 2002; Spirig et al., 2005; Brunner et al., 2007), and in laboratory studies of VOC chemistry and aerosol particle formation (e.g. Wisthaler et al., 2001; Paulsen et al., 2005; Lee et al., 2006a,b; Vartiainen et al., 2006). Much has been learned also about the performance, sensitivity, and specificity of the PTR-MS instrument (e.g. Hayward et al., 2002; de Gouw et al., 2003a,b; Tani et al., 2003, 2004; Warneke et al., 2003; Ammann et al., 2004; Steinbacher et al., 2004).

Most of the field work with PTR-MS has been conducted in intensive short-term measurement campaigns. In these campaigns, other VOC measurement techniques have often been applied simultaneously with PTR-MS, which has helped the validation and interpretation of the PTR-MS data. The approach to long-term stand-alone field measurements by PTR-MS has to be straightforward to facilitate the acquisition and analysis of the data. It is important that the measurement, calibration, and mixing ratio calculation methods are systematic, practical, and as automatic as reasonable. The PTR-MS instrument has to be calibrated regularly to achieve and maintain the accuracy needed in atmospheric VOC measurements. However, in many cases there are no calibration gas standards available for all VOCs measured with PTRMS. Therefore, it is beneficial if the information obtained from a calibration can be utilized to get consistent results also for the compounds not present in a calibration gas standard.

Our group at the University of Helsinki has been using PTR-MS since 2004 and we have focused on long-term field measurements of biogenic VOCs. The experimental work has been carried out in a boreal forest ecosystem at the SMEAR II (Station for Measuring Ecosystem-Atmosphere Relations II) measurement station in southern Finland (Hari and Kulmala, 2005). Rinne et al. (2005, 2007) have reported the first results from ambient mixing ratio measurements and micrometeorological flux measurements with the disjunct eddy covariance technique. Ruuskanen et al. (2005) have presented a dynamic shoot chamber system, which is suitable for field experiments and combines PTR-MS measurements of VOC emissions with measurements of other trace gases and environmental variables that contribute to the gas exchange of trees.

The aim of this paper is to give a detailed description of our measurement, calibration, and volume mixing ratio calculation methods, which have been designed for long-term stand-alone field measurements by PTR-MS. First, we describe the measurement and calibration setups and routines, and next, we explicitly present the method for calculating volume mixing ratios. We show how the data from a calibration can be used to determine the sensitivity of the instrument for VOCs in a calibration gas standard and an instrument specific relative transmission curve. This curve enables consistent mixing ratio calculation for VOCs not present in the gas standard. Finally, to illustrate the functionality of all these methods, we present a one-month period of ambient mixing ratio data for formaldehyde, methanol, benzene, and monoterpenes. The three latter compounds were present in our calibration gas standard while the first one was not. A longer time series has been presented in an accompanying paper (Ruuskanen et al., 2008). These measurements were part of an EUCAARI (European Integrated Project on 


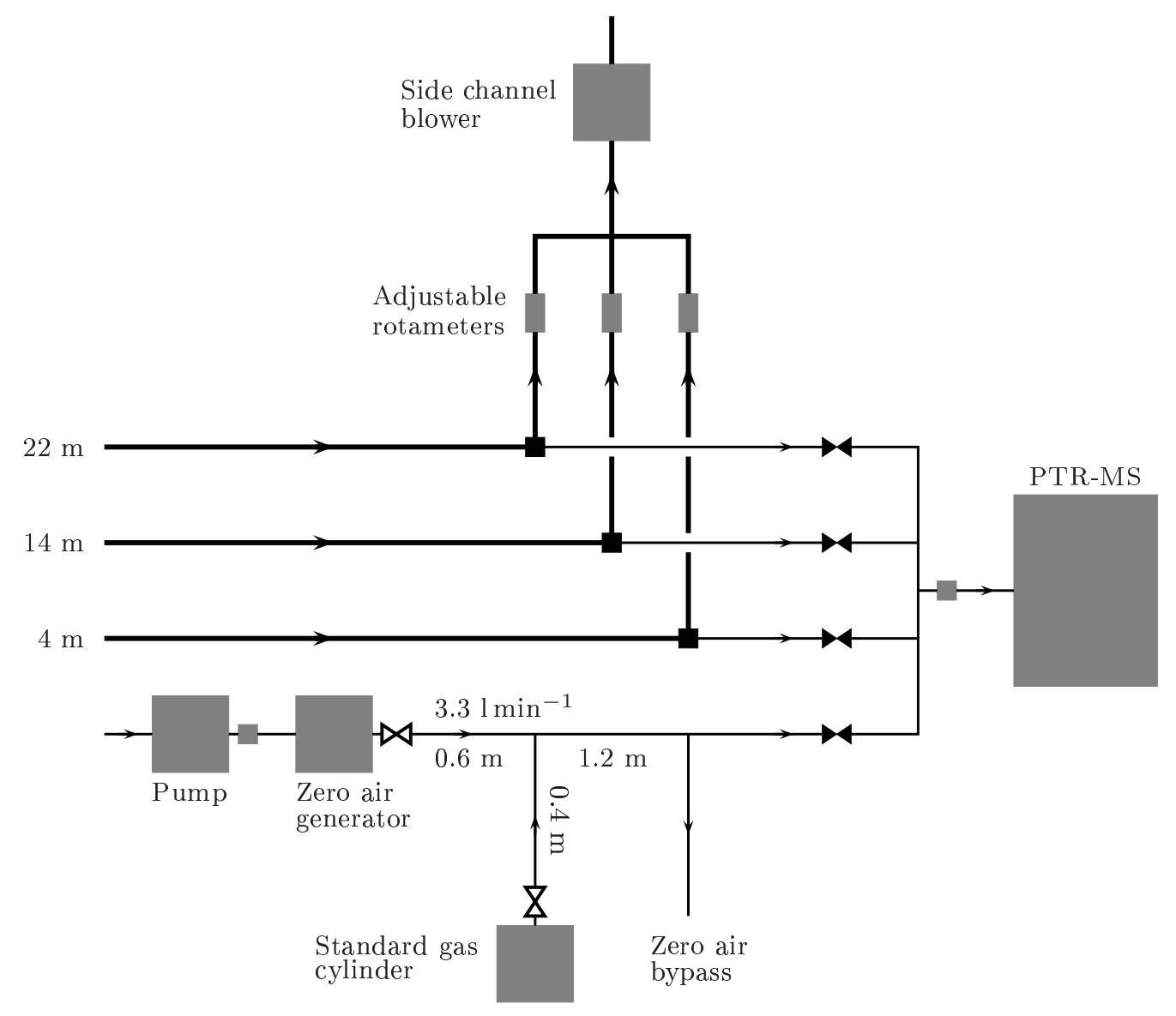

\footnotetext{
- T-connector (PTFE) Filter (PTFE)

- PTFE tubing: flow $17.5 \mathrm{lmin}^{-1}$, inner diameter $8 \mathrm{~mm}$, length $30 \mathrm{~m}$ from the sampling height to the T-connector

- PTFE tubing: flow $0.1 \mathrm{l} \mathrm{min}^{-1}$, inner diameter $1.6 \mathrm{~mm}$, length $1.3 \mathrm{~m}$ from the T-connector or the zero air bypass to the PTR-MS inlet
}

Fig. 1. Measurement and calibration setup used for long-term measurements of VOC mixing ratios by PTR-MS. The sampling heights were 4,14 , and $22 \mathrm{~m}$.

Aerosol-Cloud-Climate and Air Quality Interactions) measurement campaign, which was carried out at the SMEAR II station in March-June 2007.

\section{Methods}

\subsection{Measurement site}

The measurements were conducted at the SMEAR II (Station for Measuring Ecosystem-Atmosphere Relations II) measurement station of the University of Helsinki. The research at the station consists of continuous and comprehensive longterm measurements to study energy and material flows be- tween the forest ecosystem and the atmosphere at different temporal and spatial scales (e.g. Hari and Kulmala, 2005). The station is located in the south boreal vegetation zone at Hyytiälä, southern Finland ( $61^{\circ} 51^{\prime}$ N, $24^{\circ} 17^{\prime}$ E, 180 m a.s.l.), about $200 \mathrm{~km}$ to the north-west from Helsinki. The largest city near the station is Tampere, located $50 \mathrm{~km}$ to the southwest and having about 200000 inhabitants. A detailed description of the station has been given by Vesala et al. (1998) and Kulmala et al. (2001).

The station is situated at a rather homogeneous 46-yearold Scots pine (Pinus sylvestris) forest. Of the area of $1600 \mathrm{~km}^{2}$ around the station, spruce dominated forest covers $26 \%$, pine dominated forest $23 \%$, mixed forest $21 \%$, 
Table 1. PTR-MS measurement cycle in the ambient volume mixing ratio measurements, the compounds contributing to the measured masses, and the PTR-MS integration, or dwell, times $(\tau)$. The cycle length was $38 \mathrm{~s}$. The last column contains the detection limits (DL) suitable for individual measurements with an integration time of $2.0 \mathrm{~s}$.

\begin{tabular}{|c|c|c|c|c|}
\hline \multicolumn{2}{|c|}{$\begin{array}{l}\text { Protonated mass [amu] and } \\
\text { contributing compound(s) }\end{array}$} & \multirow{3}{*}{$\begin{array}{l}\text { Formula } \\
\mathrm{H}_{2}{ }^{18} \mathrm{O}^{*}\end{array}$} & \multirow{3}{*}{$\begin{array}{c}\tau \\
{[\mathrm{s}]}\end{array}$} & \multirow[t]{3}{*}{$\begin{array}{c}\text { DL } \\
\text { [pptv] }\end{array}$} \\
\hline 21 & water isotopes & & & \\
\hline 25 & (control mass) & & & \\
\hline 31 & formaldehyde & $\mathrm{CH}_{2} \mathrm{O}$ & 2.0 & 98 \\
\hline 32 & oxygen $\bullet$ & $\mathrm{O}_{2}$ & 0.2 & \\
\hline 33 & methanol & $\mathrm{CH}_{4} \mathrm{O}$ & 2.0 & 300 \\
\hline 39 & water cluster isotopes & $\mathrm{H}_{2} \mathrm{OH}_{2}{ }^{18} \mathrm{O}^{*}$ & 0.2 & \\
\hline 42 & acetonitrile & $\mathrm{C}_{2} \mathrm{H}_{3} \mathrm{~N}$ & 2.0 & 15 \\
\hline 45 & acetaldehyde & $\mathrm{C}_{2} \mathrm{H}_{4} \mathrm{O}$ & 2.0 & 76 \\
\hline 59 & acetone & $\mathrm{C}_{3} \mathrm{H}_{6} \mathrm{O}$ & 2.0 & 74 \\
\hline 69 & $\begin{array}{l}\text { isoprene } \\
\text { methylbutenol fragments }\end{array}$ & $\mathrm{C}_{5} \mathrm{H}_{8}$ & 2.0 & 53 \\
\hline 71 & $\begin{array}{l}\text { methacrolein } \\
\text { methyl vinyl ketone }\end{array}$ & $\begin{array}{l}\mathrm{C}_{4} \mathrm{H}_{6} \mathrm{O} \\
\mathrm{C}_{4} \mathrm{H}_{6} \mathrm{O}\end{array}$ & 2.0 & 52 \\
\hline 73 & methyl ethyl ketone & $\mathrm{C}_{4} \mathrm{H}_{8} \mathrm{O}$ & 2.0 & 36 \\
\hline 79 & benzene & $\mathrm{C}_{6} \mathrm{H}_{6}$ & 2.0 & 18 \\
\hline 81 & $\begin{array}{l}\text { monoterpene fragments } \\
\text { hexenal fragments }\end{array}$ & & 2.0 & 58 \\
\hline 87 & methylbutenol & $\mathrm{C}_{5} \mathrm{H}_{10} \mathrm{O}$ & 2.0 & 47 \\
\hline 93 & toluene & $\mathrm{C}_{7} \mathrm{H}_{8}$ & 2.0 & 60 \\
\hline 99 & hexenal & $\mathrm{C}_{6} \mathrm{H}_{10} \mathrm{O}$ & 2.0 & 63 \\
\hline 101 & $\begin{array}{l}\text { cis-3-hexenol } \\
\text { hexanal }\end{array}$ & $\begin{array}{l}\mathrm{C}_{6} \mathrm{H}_{12} \mathrm{O} \\
\mathrm{C}_{6} \mathrm{H}_{12} \mathrm{O}\end{array}$ & 2.0 & 660 \\
\hline 113 & & & 2.0 & 53 \\
\hline 137 & monoterpenes & $\mathrm{C}_{10} \mathrm{H}_{16}$ & 2.0 & 46 \\
\hline 141 & & & 2.0 & 46 \\
\hline 169 & $\begin{array}{l}\text { monoterpene oxidation } \\
\text { products }\end{array}$ & $\mathrm{C}_{10} \mathrm{H}_{16} \mathrm{O}_{2}$ & 2.0 & 79 \\
\hline
\end{tabular}

* the most abundant isotopes

- molecular mass

water bodies $13 \%$, and agriculture $10 \%$ (for details, see Haapanala et al., 2007). In addition to the ambient mixing ratio and shoot and ecosystem scale emission measurements with PTR-MS (Rinne et al., 2005, 2007; Ruuskanen et al., 2005), several VOC measurements have been conducted at the SMEAR II station using gas chromatographic analyses of air samples collected on adsorbents or in canisters (e.g. Rinne et al., 2000; Janson and de Serves, 2001; Hakola et al., 2003, 2006; Tarvainen et al., 2005).

\subsection{Measurement setup and procedure}

Our measurement setup consisted of a proton transfer reaction mass spectrometer (PTR-MS, Ionicon Analytik GmbH), a sampling system, and a calibration system (Fig. 1). The setup was installed in an air-conditioned measurement cabin. There were three sampling lines in the sampling system and they were used for ambient mixing ratio measurements at different heights. The lowest sampling height $(4 \mathrm{~m})$ was located in the trunk space of the canopy, the middle one $(14 \mathrm{~m})$ in the crown space of the canopy, and the highest one $(22 \mathrm{~m})$ above the top of the canopy. The sampling lines were attached to a measurement tower next to the cabin and heated a few degrees warmer than ambient air with Teflon-coated heating cables. All lines were $30 \mathrm{~m}$ long, their inner diameter was $8 \mathrm{~mm}$, and they were made of Teflon (PTFE). A continuous flow of $17.51 \mathrm{~min}^{-1}$ was used in each line.

A side flow of $0.11 \mathrm{~min}^{-1}$ was taken from the sampling lines into the PTR-MS via a $1.3 \mathrm{~m}$ long PTFE tubing, which had an inner diameter of $1.6 \mathrm{~mm}$. A PTFE filter $(1 \mu \mathrm{m}$ pore size, LI-COR, Inc., part number 9967-008) was installed in front of the PTR-MS inlet to prevent particles from entering the instrument. Solenoid valves (ETFE valve body, Bürkert $\mathrm{GmbH} \&$ Co., type 117) were used to switch between the sampling lines. The valves were controlled through the ana$\log$ outputs of the PTR-MS.

The PTR-MS was operating continuously during the EUCAARI measurement campaign, which was carried out in March-June 2007. In this paper, we present ambient mixing ratio data from the period 27 March-26 April. The operating parameters of the PTR-MS were held constant during the measurement period, except for the voltage of the secondary electron multiplier, which was optimized before every calibration (see Sect. 2.3). The drift tube pressure, temperature, and voltage were $2.0 \mathrm{hPa}, 50^{\circ} \mathrm{C}$, and $450 \mathrm{~V}$, respectively. The parameter $E / N$ was about $106 \mathrm{Td}$ and the reaction time was about $120 \mu$ s (see Sect. 2.4). The count rate of $\mathrm{H}_{3} \mathrm{O}^{+} \mathrm{H}_{2} \mathrm{O}$ ions was $6-34 \%$ of the count rate of $\mathrm{H}_{3} \mathrm{O}^{+}$ions, which was $(2.1-5.4) \times 10^{6}$ counts s $^{-1}$.

The measurement procedure was controlled with the Balzers Quadstar 422 software of the PTR-MS and it contained three hour-long sequences. Every third hour was allocated for the ambient mixing ratio measurements at the three sampling heights and for mass scan measurements at $14 \mathrm{~m}$ above the ground. The other two sequences were allocated for ecosystem scale flux measurements with the micrometeorological disjunct eddy covariance method and for shoot scale flux measurements with a dynamic chamber method.

In the ambient mixing ratio measurements, five PTR-MS measurement cycles were conducted using the same sampling height and after that the height was switched. This sampling cycle was repeated five times an hour. The PTRMS measurement cycle consisted of 22 masses and 18 of them were related to VOCs (Table 1). The measurement cycle length was $38 \mathrm{~s}$ and the integration, or dwell, time was $2 \mathrm{~s}$ for each VOC-related mass. To determine VOC background signals of the PTR-MS, zero air measurements, where VOCfree air was fed into the instrument (see Sect. 2.3), were conducted every third hour within the ecosystem scale flux measurement sequence, right before the ambient mixing ratio 
Table 2. Compositions of the calibration gas standards. The standard A was used in the calibrations conducted in March and April 2007 and the standard B was used in July and August 2007. The manufacturer (Apel-Riemer Environmental, Inc.) estimated that the uncertainty of the volume mixing ratio (VMR) was not more than $6 \%$ for cis-3-hexenol and methyl vinyl ketone (in A) and not more than $5 \%$ for the other compounds. The last column contains the proton transfer reaction rate coefficients $(k)$ reported by Zhao and Zhang (2004).

\begin{tabular}{|c|c|c|c|c|c|}
\hline \multicolumn{2}{|c|}{$\begin{array}{l}\text { VOC and its protonated mass } \\
\text { [amu] }\end{array}$} & Formula & $\begin{array}{l}\text { VMR in A } \\
\text { [ppmv] }\end{array}$ & \multirow{2}{*}{$\begin{array}{c}\begin{array}{c}\text { VMR in B } \\
\text { [ppmv] }\end{array} \\
1.05\end{array}$} & \multirow{2}{*}{ 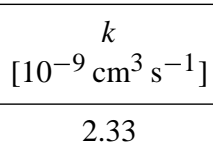 } \\
\hline 33 & methanol & $\mathrm{CH}_{4} \mathrm{O}$ & 1.03 & & \\
\hline 42 & acetonitrile & $\mathrm{C}_{2} \mathrm{H}_{3} \mathrm{~N}$ & 1.08 & 1.01 & 4.74 \\
\hline 45 & acetaldehyde & $\mathrm{C}_{2} \mathrm{H}_{4} \mathrm{O}$ & 1.06 & 0.99 & 3.36 \\
\hline 47 & ethanol & $\mathrm{C}_{2} \mathrm{H}_{6} \mathrm{O}$ & 1.06 & - & \\
\hline 59 & acetone & $\mathrm{C}_{3} \mathrm{H}_{6} \mathrm{O}$ & 1.09 & 1.05 & \\
\hline 69 & isoprene & $\mathrm{C}_{5} \mathrm{H}_{8}$ & 1.09 & 1.02 & \\
\hline 71 & methacrolein & $\mathrm{C}_{4} \mathrm{H}_{6} \mathrm{O}$ & 1.08 & - & 3.55 \\
\hline 71 & methyl vinyl ketone & $\mathrm{C}_{4} \mathrm{H}_{6} \mathrm{O}$ & 0.92 & 0.92 & 3.83 \\
\hline 73 & methyl ethyl ketone & $\mathrm{C}_{4} \mathrm{H}_{8} \mathrm{O}$ & 1.08 & 1.06 & 3.48 \\
\hline 79 & benzene & $\mathrm{C}_{6} \mathrm{H}_{6}$ & 1.07 & 1.03 & 1.97 \\
\hline 93 & toluene & $\mathrm{C}_{7} \mathrm{H}_{8}$ & 1.07 & 1.04 & 2.12 \\
\hline 101 & cis-3-hexenol & $\mathrm{C}_{6} \mathrm{H}_{12} \mathrm{O}$ & 0.96 & - & \\
\hline 101 & hexanal & $\mathrm{C}_{6} \mathrm{H}_{12} \mathrm{O}$ & 0.97 & 0.90 & \\
\hline 107 & m-xylene & $\mathrm{C}_{8} \mathrm{H}_{10}$ & 1.07 & 1.03 & 2.26 \\
\hline 107 & o-xylene & $\mathrm{C}_{8} \mathrm{H}_{10}$ & 1.07 & 1.05 & 2.32 \\
\hline 121 & 1,2,4-trimethylbenzene & $\mathrm{C}_{9} \mathrm{H}_{12}$ & - & 0.98 & 2.40 \\
\hline 129 & naphthalene & $\mathrm{C}_{10} \mathrm{H}_{8}$ & - & 1.00 & 2.59 \\
\hline 137 & $\alpha$-pinene & $\mathrm{C}_{10} \mathrm{H}_{16}$ & 1.05 & 0.93 & \\
\hline 182 & 1,2,4-trichlorobenzene & $\mathrm{C}_{6} \mathrm{H}_{3} \mathrm{Cl}_{3}$ & - & 1.01 & \\
\hline
\end{tabular}

- These compounds do not fragment significantly in the drift tube of the PTR-MS. They were taken into account in the determination of a relative transmission curve, except for 1,2,4-trichlorobenzene.

measurements. Zero air was measured for about 8 min (12 cycles) at a time and the integration time was $2 \mathrm{~s}$ for each VOC-related mass.

\subsection{Calibration setup and procedure}

The calibration setup (Fig. 1) consisted of a calibration gas standard (Apel-Riemer Environmental, Inc.) and a zero air generator (catalytic converter, Parker Hannifin Corp., ChromGas Zero Air Generator 3501). The calibration gas standard contained 16 VOCs in nitrogen and the mixing ratio of each VOC was about 1 ppmv (part per million by volume; Table 2). Ambient air was fed with an oil-free piston pump (Gardner Denver Thomas, Inc., model number 688CGHI32) through a PTFE filter $(1 \mu \mathrm{m}$ pore size, LI-COR, Inc., part number 9967-008) into the zero air generator to produce VOC-free air that was used in calibration measurements to dilute the standard gas. Normally, the standard gas was diluted to a mixing ratio range of $15-20 \mathrm{ppbv}$ (parts per billion by volume). The standard gas flow (about $60 \mathrm{ml} \mathrm{min}^{-1}$ ) and the zero air flow (about $3260 \mathrm{ml} \mathrm{min}^{-1}$ ) were regulated using needle valves (stainless steel, Swagelok Co., part number SS-SS2) and the flows were measured during each calibration using a primary flow meter (Bios International Corp., DryCal DC-2M). The flow meter was installed in the calibra- tion system only during the flow measurement. PTFE tubing (1.6 $\mathrm{mm}$ inner diameter) was used in the calibration lines and the calibration system was connected to the PTR-MS in the same way as the main sampling lines. The calibration system was utilized also in the zero air measurements.

The PTR-MS was calibrated four times during the measurement period: on 27 March, 3 April, 13 April, and 18 April. The calibration procedure contained three stages. First, zero air was measured for about $30 \mathrm{~min}$ (67 cycles), then the standard gas cylinder was opened and a mixture of zero air and standard gas was fed into the PTR-MS for about $90 \mathrm{~min}$ (200 cycles), and finally, the standard gas cylinder was closed and zero air was measured again for at least $30 \mathrm{~min}$. The standard gas flow and the zero air flow were measured right before the gas cylinder was closed. The flows were not changed during the calibration, so each of the four calibrations was performed at a single VOC mixing ratio.

In addition to the protonated masses of the VOCs in the calibration gas standard (Table 2), masses of some fragmentation products were measured in the calibrations. Fragments of isoprene were detected at $41 \mathrm{amu}$ (M41), fragments of acetone at M43, fragments of $\alpha$-pinene at M81, M82, and M95, and fragments of cis-3-hexenol and hexanal at M83 (de Gouw et al., 2003b; Tani et al., 2003; Warneke et al., 2003; Ammann et al., 2004; de Gouw and Warneke, 2007). 
The length of the PTR-MS measurement cycle was $27 \mathrm{~s}$ and the integration time was $1 \mathrm{~s}$ for each VOC-related mass.

The detection efficiency of the secondary electron multiplier (SEM; MasCom GmbH, model MC-217) was checked before every calibration. In these tests, zero air was fed into the PTR-MS and the operating voltage of the SEM was increased by $50 \mathrm{~V}$ steps. The signals of the primary ion isotopes (M21) and isoprene (M69) were recorded and the optimal SEM voltage was chosen so that the signals did not increase more than $20 \%$ when the voltage was increased by $100 \mathrm{~V}$. The optimal voltage was $2000 \mathrm{~V}$ in 27 March-13 April and $2100 \mathrm{~V}$ in 13-26 April. Each calibration was considered valid until the next SEM test.

To illustrate the stability of calibration over a long time scale and to explain the principle of our method for determining a relative transmission curve (see Sect. 2.4.3), we present results also from the calibrations conducted on $31 \mathrm{July}, 8 \mathrm{Au}-$ gust, 15 August, and 21 August 2007. The calibration setup and procedure were similar as in March and April, except for the calibration gas standard (Table 2). The optimal SEM voltage was $2550 \mathrm{~V}$ in 31 July-8 August, $2600 \mathrm{~V}$ in $8-21$ August, and $2650 \mathrm{~V}$ in 21-28 August.

\subsection{Volume mixing ratio measurements by PTR-MS}

The development and technical properties of the commercial PTR-MS (Ionicon Analytik GmbH) have been discussed in detail by Hansel et al. (1995), Lindinger et al. (1998a,b), and de Gouw and Warneke (2007). Briefly, the instrument consists of four main components: an ion source, a drift tube, a mass spectrometer, and an ion detector. Primary ions $\left(\mathrm{H}_{3} \mathrm{O}^{+}\right)$ are produced from pure water vapour within the hollow cathode discharge ion source. The proton transfer reactions between the primary ions and VOCs take place in the drift tube, which is maintained at a pressure of approximately $2 \mathrm{hPa}$. An electric field is applied in the axial direction of the drift tube and ambient air is continuously pumped through the tube at a flow rate of about $10 \mathrm{ml} \mathrm{min}{ }^{-1}$. The primary and product ions are selected according to their molecular masses (to be exact, according to their mass-to-charge ratios) using a quadrupole mass spectrometer and detected as count rates by a secondary electron multiplier. As only a single (integer) mass can be selected at a time, different masses must be measured successively. An integration, or dwell, time can be predetermined for each mass, which enables longer integration times to be applied when expected volume mixing ratios are low and vice versa. This increases experimental precision for VOCs at low mixing ratios.

Due to their low proton affinities, the major components of air do not react with the primary ions in the drift tube. However, VOCs possessing a proton affinity higher than that of water $\left(691 \mathrm{~kJ} \mathrm{~mol}^{-1}\right)$ are ionized in proton transfer reactions:

$\mathrm{H}_{3} \mathrm{O}^{+}+\mathrm{R} \rightarrow \mathrm{RH}^{+}+\mathrm{H}_{2} \mathrm{O}$.
The number concentration of $\mathrm{RH}^{+}$ions produced in Reaction (R1) is given by

$\left[\mathrm{RH}^{+}\right]=\left[\mathrm{H}_{3} \mathrm{O}^{+}\right]_{0}\left(1-e^{-k[\mathrm{R}] \Delta t}\right) \approx\left[\mathrm{H}_{3} \mathrm{O}^{+}\right] k[\mathrm{R}] \Delta t$

(e.g. Lindinger et al., 1998a; de Gouw et al., 2003a; de Gouw and Warneke, 2007). In this equation, $\left[\mathrm{H}_{3} \mathrm{O}^{+}\right]_{0}$ is the number concentration of the primary ions injected from the ion source, $k$ is the proton transfer reaction rate coefficient, and $[R]$ is the number concentration of the compound $R$ in the drift tube. The reaction time, $\Delta t$, is determined by the length of the drift tube, $L$, and the average drift velocity, $v_{\text {drift }}$ :

$\Delta t=\frac{L}{v_{\mathrm{drift}}}=L\left(\mu_{0} N_{0} \frac{E}{N}\right)^{-1}$

(de Gouw et al., 2003a; de Gouw and Warneke, 2007), where $\mu_{0}$ is the reduced, or normalized, ion mobility of the primary ions and $N_{0}$ is the number density of air at the standard pressure $(1013.25 \mathrm{hPa})$ and temperature $(273.15 \mathrm{~K})$. The electric field over the length of the drift tube, $E=U_{\text {drift }} / L$, is determined by the drift tube voltage, $U_{\text {drift }}$. The drift tube pressure, $p_{\text {drift }}$, and temperature, $T_{\text {drift }}$, determine the number density of the gas in the drift tube, $N=N_{\mathrm{A}} p_{\text {drift }} /\left(R T_{\text {drift }}\right)$, where $N_{\mathrm{A}}$ is Avogadro's constant and $R$ is the molar gas constant.

The approximation in Eq. (1) is justified if the term $k[\mathrm{R}] \Delta t$ is small, i.e., if only a small fraction of the primary ions reacts in the drift tube. Equation (1) shows that under these conditions $\left[\mathrm{RH}^{+}\right]$is linearly proportional to $[\mathrm{R}]$ and $\left[\mathrm{H}_{3} \mathrm{O}^{+}\right]$, the number concentration of the primary ions at the end of the drift tube. If $[R]$ is too high, the approximation is no longer valid and the production of $\mathrm{RH}^{+}$ions is non-linear in [R], which should be avoided.

\subsubsection{Calculation of volume mixing ratios}

There are some important issues that have to be considered before Eq. (1) is used to calculate the volume mixing ratio of the compound R. Since the observed ion count rates, $I\left(\mathrm{RH}^{+}\right)$for $\mathrm{RH}^{+}$ions and $I\left(\mathrm{H}_{3} \mathrm{O}^{+}\right)$for $\mathrm{H}_{3} \mathrm{O}^{+}$ions, are linearly proportional to the respective number concentrations in the drift tube (de Gouw et al., 2003a), Eq. (1) can be written as

$[\mathrm{R}]=\frac{1}{k \Delta t} \frac{I\left(\mathrm{RH}^{+}\right)}{T\left(\mathrm{RH}^{+}\right)}\left(\frac{I\left(\mathrm{H}_{3} \mathrm{O}^{+}\right)}{T\left(\mathrm{H}_{3} \mathrm{O}^{+}\right)}\right)^{-1}$.

The coefficients $T\left(\mathrm{RH}^{+}\right)$and $T\left(\mathrm{H}_{3} \mathrm{O}^{+}\right)$are the transmission efficiencies for $\mathrm{RH}^{+}$and $\mathrm{H}_{3} \mathrm{O}^{+}$ions, respectively, and their values range between zero and one. They are determined by the extraction efficiency of ions from the drift tube into the quadrupole mass spectrometer, the transmission efficiency of the mass spectrometer, and the detection efficiency of the SEM. The transmission coefficients are mainly mass dependent but they vary also over time (de Gouw et al., 2003a; Ammann et al., 2004; Steinbacher et al., 2004). 
Usually, the signal of the primary ion isotopes detected at $21 \mathrm{amu}$ (M21) is measured instead of the primary ion signal detected at $19 \mathrm{amu}$ (e.g. Ammann et al., 2004). In this case, the primary ion count rate is calculated using the relation $I\left(\mathrm{H}_{3} \mathrm{O}^{+}\right)=I(\mathrm{M} 19)=487 \times I(\mathrm{M} 21)$, where the factor 487 is determined by the isotope ratio including both hydrogen and oxygen isotopes ${ }^{1}$. The direct measurement of the primary ion signal would significantly shorten the lifetime of the SEM since the value of $I$ (M19) is typically higher than $3 \times 10^{6}$ counts s $^{-1}$ (cps).

Although PTR-MS uses a soft chemical ionization method, which leads to lower fragmentation than many methods used in gas chromatographic techniques, it has been observed that several VOCs fragment in the drift tube of the PTR-MS (e.g. Tani et al., 2003; Warneke et al., 2003; de Gouw and Warneke, 2007). In addition, the primary ions can cluster with water molecules in the sampled air and the formed water cluster ions $\left(\mathrm{H}_{3} \mathrm{O}^{+} \mathrm{H}_{2} \mathrm{O}, \mathrm{H}_{3} \mathrm{O}^{+}\left(\mathrm{H}_{2} \mathrm{O}\right)_{2}\right.$, etc.) can ionize VOCs via proton transfer and ligand switching reactions (e.g. Warneke et al., 2001; Tani et al., 2004). Both fragmentation and cluster ion formation depend strongly on the parameter $E / N$, the ratio of the electric field to the number density of the gas in the drift tube, which is usually expressed in units of Townsend $\left(1 \mathrm{Td}=10^{-17} \mathrm{~V} \mathrm{~cm}^{2}\right)$. The degree of fragmentation increases and the degree of cluster ion formation decreases when the parameter $E / N$ is increased. Cluster ion formation depends also on the humidity of the sampled air (Warneke et al., 2001; Ammann et al., 2006).

To take the effects of fragmentation and water cluster ion formation into account, we added a fragmentation coefficient for $\mathrm{RH}^{+}$ions, $F\left(\mathrm{RH}^{+}\right)$, and the count rate of $\mathrm{H}_{3} \mathrm{O}^{+} \mathrm{H}_{2} \mathrm{O}$ ions, $I\left(\mathrm{H}_{3} \mathrm{O}^{+} \mathrm{H}_{2} \mathrm{O}\right)$, to Eq. (3), which then changes to the form

$$
\begin{aligned}
{[\mathrm{R}] } & =\frac{1}{k \Delta t} \frac{I\left(\mathrm{RH}^{+}\right)}{F\left(\mathrm{RH}^{+}\right) T\left(\mathrm{RH}^{+}\right)}\left(\frac{I\left(\mathrm{H}_{3} \mathrm{O}^{+}\right)}{T\left(\mathrm{H}_{3} \mathrm{O}^{+}\right)}+\frac{I\left(\mathrm{H}_{3} \mathrm{O}^{+} \mathrm{H}_{2} \mathrm{O}\right)}{T\left(\mathrm{H}_{3} \mathrm{O}^{+} \mathrm{H}_{2} \mathrm{O}\right)}\right)^{-1} \\
& =\frac{1}{k \Delta t} \frac{I\left(\mathrm{RH}^{+}\right)}{F\left(\mathrm{RH}^{+}\right) T\left(\mathrm{RH}^{+}\right)}\left(\frac{I\left(\mathrm{H}_{3} \mathrm{O}^{+}\right)}{T\left(\mathrm{H}_{3} \mathrm{O}^{+}\right)}+\frac{I\left(\mathrm{H}_{3} \mathrm{O}^{+} \mathrm{H}_{2} \mathrm{O}\right)}{\alpha T\left(\mathrm{H}_{3} \mathrm{O}^{+}\right)}\right)^{-1} \\
& =\frac{1}{k \Delta t} \frac{T\left(\mathrm{H}_{3} \mathrm{O}^{+}\right)}{F\left(\mathrm{RH}^{+}\right) T\left(\mathrm{RH}^{+}\right)} \frac{I\left(\mathrm{RH}^{+}\right)}{I\left(\mathrm{H}_{3} \mathrm{O}^{+}\right)+\alpha^{-1} I\left(\mathrm{H}_{3} \mathrm{O}^{+} \mathrm{H}_{2} \mathrm{O}\right)} .
\end{aligned}
$$

In this equation, $F\left(\mathrm{RH}^{+}\right)$gives the proportion of $\mathrm{RH}^{+}$ ions to all product ions (i.e., $\mathrm{RH}^{+}$and fragment ions) formed in the proton transfer reactions between the primary and water cluster ions and the compound R. For non-fragmenting compounds $F\left(\mathrm{RH}^{+}\right)=1$. The new variable $\alpha=T\left(\mathrm{H}_{3} \mathrm{O}^{+} \mathrm{H}_{2} \mathrm{O}\right) / T\left(\mathrm{H}_{3} \mathrm{O}^{+}\right)$is the ratio of the transmission coefficient for the water cluster ions to that for the primary ions. Since the values of $T\left(\mathrm{H}_{3} \mathrm{O}^{+}\right)$and $T\left(\mathrm{H}_{3} \mathrm{O}^{+} \mathrm{H}_{2} \mathrm{O}\right)$ are difficult to determine directly, we introduced this new approach to taking account of the abundance of the water cluster ions.

\footnotetext{
${ }^{1}$ Isotope Pattern Calculator v4.0: http://www.geocities.com/ junhuayan/pattern.htm, access: 10 September 2008.
}

We estimated the value of $\alpha$ after every calibration using an iterative approach in our method for determining a relative transmission curve (see Sect. 2.4.3). In this approach, we started from an initial input value of $\alpha=1$ and increased that value until it was practically equal to the one determined from the corresponding relative transmission curve (see Fig. 3). The value of $\alpha$ ranged from 1.25 to 1.46.

To extend the lifetime of the SEM, we measured the signal of the water cluster ion isotopes detected at M39 instead of the water cluster ion signal detected at M37. We calculated the water cluster ion count rate using the relation $I\left(\mathrm{H}_{3} \mathrm{O}^{+} \mathrm{H}_{2} \mathrm{O}\right)=I(\mathrm{M} 37)=243 \times I(\mathrm{M} 39)$, where the factor 243 is determined by the isotope ratio including both hydrogen and oxygen isotopes ${ }^{2}$. To decrease the instrumental noise in the primary and water cluster ion count rate, we smoothed the observed count rates by using a five-minute running average. Because benzene (M79) and toluene (M93) react only slowly with the water cluster ions (Warneke et al., 2001; de Gouw et al., 2003b), we omitted the term $\alpha^{-1} I\left(\mathrm{H}_{3} \mathrm{O}^{+} \mathrm{H}_{2} \mathrm{O}\right)$ from Eq. (4) when calculating mixing ratios from the signals detected at M79 and M93.

In PTR-MS measurements, significant offset count rates are normally observed for many VOC-related masses. They are most likely caused by desorption of impurities inside the instrument and the sampling system (Steinbacher et al., 2004). To take account of these VOC background signals, we subtracted the average of the ion count rate observed in the zero air measurements from the count rate observed in the actual measurements:

$$
\begin{aligned}
{[\mathrm{R}]=} & \frac{1}{k \Delta t} \frac{T\left(\mathrm{H}_{3} \mathrm{O}^{+}\right)}{F\left(\mathrm{RH}^{+}\right) T\left(\mathrm{RH}^{+}\right)}\left[\frac{I\left(\mathrm{RH}^{+}\right)}{I\left(\mathrm{H}_{3} \mathrm{O}^{+}\right)+\alpha^{-1} I\left(\mathrm{H}_{3} \mathrm{O}^{+} \mathrm{H}_{2} \mathrm{O}\right)}\right. \\
& -\frac{1}{n} \sum_{i=1}^{n} \frac{I\left(\mathrm{RH}^{+}\right)_{\text {zero }, i}}{I\left(\mathrm{H}_{3} \mathrm{O}^{+}\right)_{\text {zero }, i}+\alpha^{-1} I\left(\mathrm{H}_{3} \mathrm{O}^{+} \mathrm{H}_{2} \mathrm{O}\right)_{\text {zero }, i}} \\
& \left.\left(\frac{p_{\text {drift, zero }, i}}{p_{\text {drift }}}\right)^{-1}\right]
\end{aligned}
$$

where the subscript zero refers to the zero air measurements, $n$ is the number of zero air measurement cycles, and $p_{\text {drift }}$ is the drift tube pressure during the actual measurements. In Eq. (5), we took into account that the primary and water cluster ion count rate as well as the drift tube pressure can vary slightly between the actual and zero air measurements.

The instruments commonly used to generate VOC-free air, such as catalytic converters and charcoal cartridges, do not necessarily remove all VOCs from the air. Further, it is possible that a compound, which is not expected to be removed by the zero air generator, contributes to the signal of a VOCrelated mass. For example, the oxygen isotope, ${ }^{16} \mathrm{O}^{17} \mathrm{O}$, is detected at the same mass as methanol (M33). Such overlap problems are probably less significant than the problem due

\footnotetext{
${ }^{2}$ Isotope Pattern Calculator v4.0: http://www.geocities.com/ junhuayan/pattern.htm, access: 10 September 2008.
} 
to the inefficiency of the zero air generator, which is difficult to quantify if there are no zero air references available. When calculating mixing ratios from the signal detected at M33, we subtracted $0.076 \%$ (the isotope ratio ${ }^{3}$ ) of the oxygen count rates (M32) observed during the actual and zero air measurements from the respective M33 count rates.

The normalized count rate of $\mathrm{RH}^{+}$ions, expressed in units of normalized counts $\mathrm{s}^{-1}$ (ncps), is frequently used in PTRMS studies to enable the comparison of signals observed in different measurements. Our definition of the normalized $\mathrm{RH}^{+}$ion count rate is

$$
\begin{aligned}
I\left(\mathrm{RH}^{+}\right)_{\text {norm }}= & I\left(\mathrm{RH}^{+}\right) \\
& \left(\frac{I\left(\mathrm{H}_{3} \mathrm{O}^{+}\right)+\alpha^{-1} I\left(\mathrm{H}_{3} \mathrm{O}^{+} \mathrm{H}_{2} \mathrm{O}\right)}{I_{\text {norm }}}\right)^{-1}\left(\frac{p_{\text {drift }}}{p_{\text {norm }}}\right)^{-1} \\
& -\frac{1}{n} \sum_{i=1}^{n} I\left(\mathrm{RH}^{+}\right)_{\text {zero }, i} \\
& \left(\frac{I\left(\mathrm{H}_{3} \mathrm{O}^{+}\right)_{\text {zero }, i}+\alpha^{-1} I\left(\mathrm{H}_{3} \mathrm{O}^{+} \mathrm{H}_{2} \mathrm{O}\right)_{\text {zero }, i}}{I_{\text {norm }}}\right)^{-1} \\
& \left(\frac{p_{\text {drift, zero }, i}}{p_{\text {norm }}}\right)^{-1} \cdot
\end{aligned}
$$

In this equation, the sum of the primary and water cluster ion count rate is normalized to a count rate of $I_{\text {norm }}=10^{6}$ cps and the drift tube pressure is normalized to a pressure of $p_{\text {norm }}=2 \mathrm{hPa}$. Our definition of the normalized count rate resembles the one proposed by Tani et al. (2004). In addition to $\mathrm{H}_{3} \mathrm{O}^{+}$and $\mathrm{H}_{3} \mathrm{O}^{+} \mathrm{H}_{2} \mathrm{O}$ ions, the equation presented by Tani et al. (2004) takes into account $\mathrm{H}_{3} \mathrm{O}^{+}\left(\mathrm{H}_{2} \mathrm{O}\right)_{2}$ ions, but it does not include the variable $\alpha$ and the subtraction of the VOC background signal.

According to Eqs. (5) and (6), the number concentration of the compound $\mathrm{R}$ is

$[\mathrm{R}]=\frac{1}{k \Delta t} \frac{T\left(\mathrm{H}_{3} \mathrm{O}^{+}\right)}{F\left(\mathrm{RH}^{+}\right) T\left(\mathrm{RH}^{+}\right)} \frac{p_{\text {drift }}}{I_{\text {norm }} p_{\text {norm }}} I\left(\mathrm{RH}^{+}\right)_{\text {norm }}$.

Finally, the number concentration can be converted into a volume mixing ratio, VMR, given in units of parts per billion by volume (ppbv, $10^{-9}$ ):

$$
\begin{aligned}
\mathrm{VMR}= & 10^{9} \frac{[\mathrm{R}]}{N} \\
= & 10^{9} \frac{p_{\text {drift }}}{I_{\text {norm }} p_{\text {norm }}} \frac{\mu_{0} N_{0}}{k L} \frac{E}{N^{2}} \frac{T\left(\mathrm{H}_{3} \mathrm{O}^{+}\right)}{F\left(\mathrm{RH}^{+}\right) T\left(\mathrm{RH}^{+}\right)} \\
& I\left(\mathrm{RH}^{+}\right)_{\text {norm }}
\end{aligned}
$$

To get this equation, we calculated the reaction time in Eq. (7) according to Eq. (2). The reaction time is slightly affected by the abundance and distribution of the water cluster ions in the drift tube (e.g. de Gouw et al., 2003a) and the proton transfer reaction rate coefficients for the water cluster ions differ somewhat from those for the primary ions.

\footnotetext{
${ }^{3}$ Isotope Pattern Calculator v4.0: http://www.geocities.com/ junhuayan/pattern.htm, access: 10 September 2008.
}

\subsubsection{Determination of normalized sensitivities}

To be able to calculate volume mixing ratios for the VOCs present in our calibration gas standard, we determined the sensitivity of the PTR-MS for these compounds by a direct calibration (Sect. 2.3). The normalized sensitivity is

$S_{\text {norm }}=\frac{I\left(\mathrm{RH}^{+}\right)_{\text {norm }}}{\mathrm{VMR}}$

and its unit is ncps ppbv ${ }^{-1}$. We calculated the normalized sensitivities from this equation using the known calibration mixing ratios and the corresponding normalized count rates. Once we had determined the normalized sensitivities, we calculated the mixing ratios for the respective compounds by solving the same equation for VMR and using the normalized count rates observed in the actual measurements.

According to Eqs. (8) and (9), the normalized sensitivity can be written as

$$
S_{\text {norm }}=10^{-9} \frac{I_{\text {norm }} p_{\text {norm }}}{p_{\text {drift }}} \frac{k L}{\mu_{0} N_{0}} \frac{N^{2}}{E} \frac{F\left(\mathrm{RH}^{+}\right) T\left(\mathrm{RH}^{+}\right)}{T\left(\mathrm{H}_{3} \mathrm{O}^{+}\right)} .
$$

This definition resembles the one given by de Gouw et al. (2003a). The differences are due to the fragmentation coefficient and our definition of the normalized count rate. Because we take the drift tube pressure into account in the normalized count rate, there is an additional term, $p_{\text {norm }} / p_{\text {drift }}$, in Eq. (10), which is not included in the normalized sensitivity defined by de Gouw et al. (2003a). The term $10^{-9} \times I_{\text {norm }}=10^{-3} \mathrm{cps}$ in our equation agrees with the factor $10^{-3}$ in the equation of de Gouw et al. (2003a).

\subsubsection{Determination of a relative transmission curve}

To be able to calculate volume mixing ratios for VOCs not present in our calibration gas standard, we developed a method for determining a relative transmission curve for the mass range M19-M170. In this method, we determine a new relative transmission curve after every calibration using the normalized sensitivities measured for those VOCs in the gas standard that do not fragment significantly (Table 2). First, we calculate relative transmission coefficients for the masses related to the non-fragmenting VOCs. According to Eq. (10), the relative transmission coefficient is

$$
T\left(\mathrm{RH}^{+}\right)_{\text {rel }}=\frac{T\left(\mathrm{RH}^{+}\right)}{T\left(\mathrm{H}_{3} \mathrm{O}^{+}\right)}=10^{9} \frac{p_{\text {drift }}}{I_{\text {norm }} p_{\text {norm }}} \frac{\mu_{0} N_{0}}{k L} \frac{E}{N^{2}} S_{\text {norm }} .
$$

For the reduced ion mobility, we use a value of $\mu_{0}=2.8 \mathrm{~cm}^{2} \mathrm{~V}^{-1} \mathrm{~s}^{-1}$, and for the proton transfer reaction rate coefficient the values reported by Zhao and Zhang (2004) (Table 2). To calculate the electric field and the number density, we use the drift tube voltage, pressure, and temperature measured during the calibration. The length of the drift tube is $9.5 \mathrm{~cm}$ in our instrument.

Depending on the gas standard used in the calibration, we calculate the relative transmission coefficient for eight or 
ten VOC-related masses (Table 2). The corresponding mass ranges are M33-M107 and M33-M129. To be able to obtain the relative transmission curve for the mass range M19M170, we determine five empirical parameters from the relative transmission coefficient data. The criteria for these parameters are: (1) The maximum of the relative transmission curve is the average of the two highest relative transmission coefficients, (2) the second parameter is the median of the relative transmission coefficients related to the masses that are smaller than the mass of the maximum point, (3) the third parameter is the median of the relative transmission coefficients related to the masses that are higher than the mass of the maximum point, (4) the relative transmission coefficient for M129 is $70 \%$ of the value calculated for M107 (m- and $\mathrm{o}-\mathrm{xylene}$ ), and (5) the relative transmission coefficient for $\mathrm{M} 170$ is $40 \%$ of the value calculated for M107. When the relative transmission coefficient for M129 is calculated directly, the fourth criterion is: The relative transmission coefficient for M151 is 70\% of the value calculated for M129 (naphthalene). The sixth parameter used for determining the relative transmission curve follows immediately from the definition of the relative transmission coefficient (Eq. 11): The relative transmission coefficient for M19 is one. Finally, the relative transmission curve is determined by fitting a piecewise cubic Hermite interpolation function (e.g. Fritsch and Carlson, 1980) to the parameters.

Since there is no theoretical basis for the shape of the relative transmission curve (Ammann et al., 2004; Steinbacher et al., 2004), we decided to use this practical method instead of a more mathematical one. However, the criteria for the parameters $1-3$ are based on the calculated relative transmission coefficients. The percentage values for the parameters 4 and 5 were estimated using medians and subjective interpretation of a data set containing information from several calibrations. In addition, the automatic implementation of our method is straightforward, which is an important advantage when the PTR-MS is used for continuous long-term measurements.

Once we had determined the relative transmission curve, we used the following equation to calculate mixing ratios for the VOCs not present in our calibration gas standard:

$\mathrm{VMR}=10^{9} \frac{p_{\text {drift }}}{I_{\text {norm }} p_{\text {norm }}} \frac{\mu_{0} N_{0}}{k L} \frac{E}{N^{2}} \sum_{i=1}^{m} \frac{I\left(\mathrm{M}_{i}\right)_{\text {norm }}}{T\left(\mathrm{M}_{i}\right)_{\text {rel }}}$,

where $m$ is the number of different product ions, $\mathbf{M}_{i}$ (i.e., $\mathrm{RH}^{+}$ions and possible fragment ions). This equation was derived from Eq. (8) using the definition of the relative transmission coefficient and the fact that $\sum_{i=1}^{m} F\left(\mathrm{M}_{i}\right)=1$. The summation is unnecessary for non-fragmenting compounds since for them $m=1$. The advantage of this equation is that it is not necessary to determine the fragmentation coefficients. It is sufficient to determine the relative transmission curve and to measure the signal of $\mathrm{RH}^{+}$ions and the signals of all the major fragmentation products. However, due to the uncertainties of the reported proton transfer reaction rate coefficients and the relative transmission curve, the accuracy of the data calculated using Eq. (12) is significantly lower than the accuracy of the data based on the measured normalized sensitivities.

\subsubsection{Determination of detection limits}

We utilized the VOC background signals observed in the zero air measurements to estimate the detection limits for all compounds measured in the ambient mixing ratio measurements (Table 1). The detection limits were calculated after every calibration from the equation $\mathrm{DL}=2 \times \sigma_{\text {zero }}$, where the factor 2 represents the $95 \%$ confidence interval of the normal distribution and $\sigma_{\text {zero }}$ is the standard deviation of the VOC background signal expressed in units of ppbv (e.g. Karl et al., 2003a). To determine $\sigma_{\text {zero }}$, we first chose a representative period of 48 PTR-MS measurement cycles from the zero air data and calculated the normalized count rate according to Eq. (6). Then we removed the linear trend from the normalized count rate, calculated the standard deviation, and converted it into a volume mixing ratio using Eq. (9) or (12). Since the PTR-MS integration time was $2 \mathrm{~s}$ for each VOCrelated mass both in the ambient mixing ratio and zero air measurements, the detection limits are suitable for individual mixing ratio measurements.

The determination of detection limits is based on the normalized count rate to avoid errors due to possible changes in the primary and water cluster ion count rate and in the drift tube pressure. The average of the background signal does not affect the detection limit since it is subtracted from the signal observed in the actual measurements when calculating volume mixing ratios (Eq. 5). Although our definition of the detection limit is somewhat loose (for a detailed discussion on detection and quantification limits, see Currie, 1968, 1999), it gives a rough estimate of the performance of our measurement setup. In addition, our method is practical to use in long-term measurements.

\section{Results and discussion}

In summary, the main principles of our measurement, calibration, and volume mixing ratio calculation methods were: (1) All procedures were systematic and practical to facilitate the acquisition and analysis of the data. (2) To achieve and maintain the accuracy needed in atmospheric VOC measurements, we calibrated the PTR-MS regularly with a gas standard. (3) We calculated the mixing ratios for the compounds in our gas standard using the measured normalized sensitivities (Eq. 9), and (4) to calculate the mixing ratios for the compounds not present in the gas standard, we determined the relative transmission curve using the information obtained from the calibrations (Eqs. 11 and 12). (5) We determined the VOC background signals frequently with a reliable 

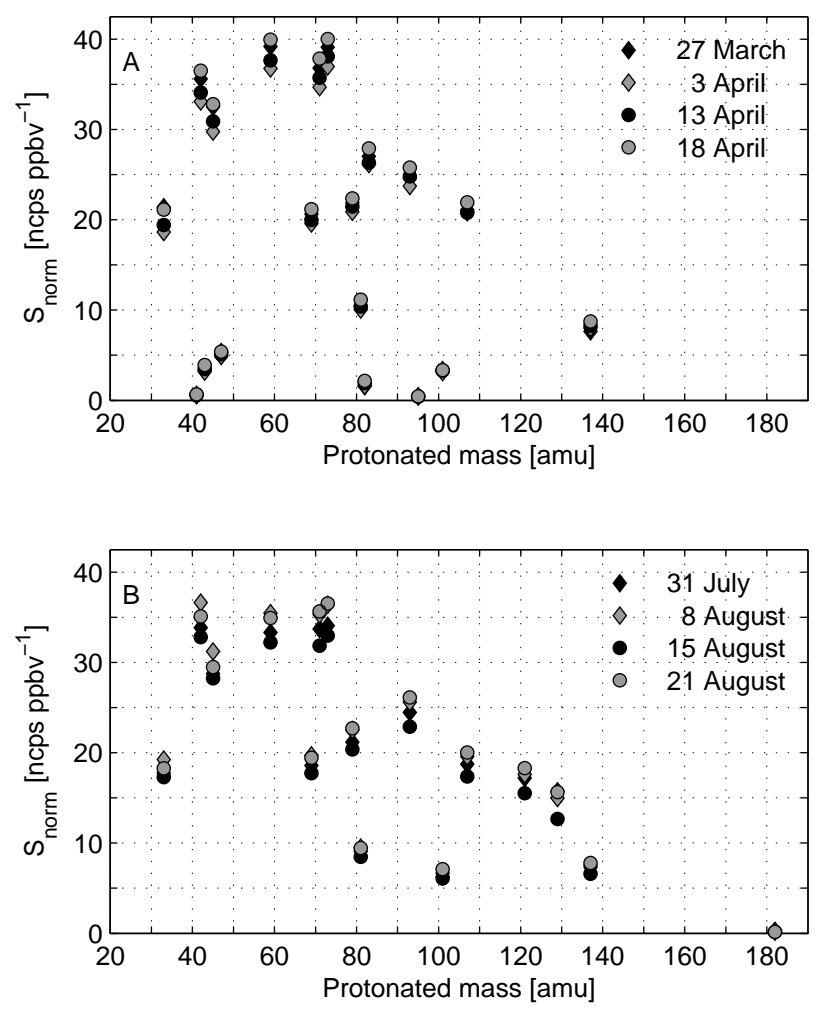

Fig. 2. Normalized sensitivities for the VOCs in the calibration gas standards. The calibration setup and procedure were similar in all calibrations, except for the gas standard (Table 2). The calibrations were performed in 2007.

zero air generator and subtracted them from the signals observed in the actual measurements. In addition, the following important details were taken into account when calculating the mixing ratios: (6) The product ion count rates were normalized using the measured primary and water cluster ion count rate and the drift tube pressure. (7) For the compounds reacting slowly with the water cluster ions, only the primary ion count rate and the drift tube pressure were used in the normalization. (8) To reduce the instrumental noise, the primary and water cluster ion count rate were smoothed using a five-minute running average. (9) The effect of fragmentation was included in the measured normalized sensitivities, and (10) for the compounds not present in the calibration gas standard, fragmentation was taken into account by summing the mixing ratios of all product ions (i.e., $\mathrm{RH}^{+}$and major fragment ions).

\subsection{Normalized sensitivities}

We calibrated the PTR-MS four times during the measurement period 27 March-26 April 2007. To illustrate the stability of calibration over a longer time scale, we present results also from four calibrations conducted in July and Au-
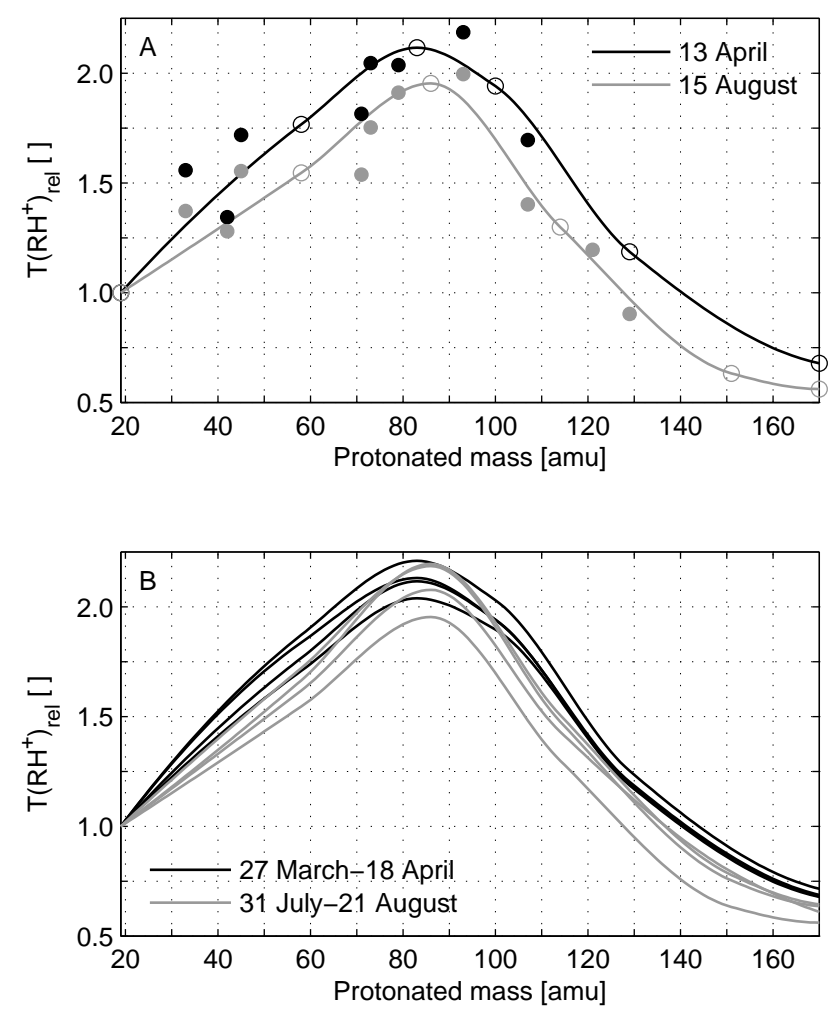

Fig. 3. Principle of the method for determining a relative transmission curve (A) and the relative transmission curves (B) derived from the calibrations shown in Fig. 2. The relative transmission coefficients (solid circles) were calculated using the measured normalized sensitivities and the parameters used for fitting the curves (open circles) were determined according to the criteria explained in Sect. 2.4.3.

gust 2007. The calibration setup and procedure were similar in all calibrations, except for the calibration gas standard (Table 2).

The normalized sensitivities shown in Fig. 2 were calculated according to Eq. (9) in all calibrations. The highest values, 28-40 ncps ppbv ${ }^{-1}$, were observed for acetonitrile (M42), acetaldehyde (M45), acetone (M59), methacrolein and methyl vinyl ketone (M71), and methyl ethyl ketone (M73). The sensitivities for methanol (M33), isoprene (M69), and benzene (M79) were 17-23 ncps ppbv ${ }^{-1}$. There was a decreasing trend between toluene (M93), m- and oxylene (M107), 1,2,4-trimethylbenzene (M121), and naphthalene (M129). The sensitivity for $\alpha$-pinene (M137) was 6.6-8.8 ncps ppbv ${ }^{-1}$ and the sensitivity for its major fragmentation product (M81) was 8.5-11 ncps ppbv ${ }^{-1}$. For $\mathrm{cis}^{-}$ 3-hexenol and hexanal (M101) the sensitivity was low, 3.1$7.1 \mathrm{ncps} \mathrm{ppbv}^{-1}$, but for their fragments (M83) it was 26-28 ncps ppbv ${ }^{-1}$ (Fig. 2a). This indicates that these compounds fragment strongly in the drift tube since the difference between the transmission coefficients for the respective masses 
cannot alone explain such a big difference in the sensitivity. The sensitivities for the fragments of isoprene (M41), acetone (M43), and $\alpha$-pinene (M82 and M95) were lower than $4.0 \mathrm{ncpspbv}^{-1}$ (Fig. 2a). These fragments seem to be minor fragmentation products in our PTR-MS under the operating conditions used in the measurements. Since the sensitivity for 1,2,4-trichlorobenzene (M182) was practically zero (Fig. 2b), it is probable that this compound did not come out of the standard gas cylinder properly.

In general, the sensitivity of our instrument was lower in July and August than in March and April. There is also variation within the data sets in Fig. 2. These facts prove that regular calibrations are needed to maintain the accuracy of PTR-MS measurements. The changes in the sensitivity can be attributed to changes in the transmission and the humidity of the sampled air. The main reason for the changes in the transmission was probably the detection efficiency of the SEM. Although we took the water cluster ions into account when calculating the normalized sensitivities (Eqs. 6 and 9), this hardly completely removed the effect of humidity.

The normalized sensitivities measured in this work are generally somewhat lower than the values measured by de Gouw et al. (2003b) and Warneke et al. (2003). The most remarkable difference is related to $\alpha$-pinene (7.7 versus 29 and $36 \mathrm{ncps} \mathrm{ppbv}^{-1}$ ). However, our definitions of the normalized count rate and the normalized sensitivity differ slightly from the ones used by de Gouw et al. (2003b) and Warneke et al. (2003), so the results are not totally comparable.

The actual sensitivity of the PTR-MS, $S=\left(I\left(\mathrm{RH}^{+}\right)-\sum_{i=1}^{n} I\left(\mathrm{RH}^{+}\right)_{\text {zero, } i} / n\right) / \mathrm{VMR}$, varied substantially within the calibrations mainly due to the changes in the abundance of the primary ions. For example, in the calibrations conducted in March and April the primary ion count rate was $(3.0-5.3) \times 10^{6} \mathrm{cps}$ and the actual sensitivity was $69-120 \mathrm{cps} \mathrm{ppbv}^{-1}$ for methanol, $67-110 \mathrm{cps} \mathrm{ppbv}^{-1}$ for benzene, and $29-47 \mathrm{cpsppbv}^{-1}$ for $\alpha$-pinene. Since the abundance of the primary ions can vary significantly within a few days or even faster, it is difficult to calibrate the PTR-MS often enough to take account of the changes in the actual sensitivity. Therefore, the use of the normalized sensitivity and the normalized count rate of $\mathrm{RH}^{+}$ions is essential in volume mixing ratio calculation.

\subsection{Relative transmission curves}

The principle of our method for determining a relative transmission curve becomes clear from Fig. 3a. The relative transmission coefficients (solid circles) were calculated from Eq. (11) using the normalized sensitivities measured for the VOCs marked with a circle in Table 2 (except for 1,2,4trichlorobenzene). These compounds do not fragment significantly and their detection is not remarkably interfered by other compounds or fragments (de Gouw et al., 2003a,b; Warneke et al., 2003; de Gouw and Warneke, 2007). The pa- rameters used for fitting the relative transmission curve (open circles) were determined according to the criteria explained in Sect. 2.4.3.

The compatibility of the relative transmission curves with the relative transmission coefficients in Fig. 3a is reasonable. For the masses below M33, the parameter for fitting the curve was the relative transmission coefficient for M19, which is one by definition. The extrapolation for the masses above M107 or M129 was based on the parameters determined using the relative transmission coefficients for M107 and M129 together with the empirical percentage values. For example, if we had extrapolated according to a straight line fitted to the relative transmission coefficients after the maximum point of the curve, the results would have been significantly lower for the masses above M150. However, according to the data collected from several calibrations during the summer 2007 (not presented in this paper), the decreasing trend between the relative transmission coefficients for M93, M107, M121, and M129 was not linear. The decrease decelerated towards the higher masses. We could also have used a non-linear extrapolation method, but it would have been applicable only in the calibrations made with the gas standard which contained 1,2,4-trimethylbenzene (M121) and naphthalene (M129). Therefore, we decided to use the more practical approach described in Sect. 2.4.3.

Our method proved to be sensitive enough to capture the changes in the transmission over time (Fig. 3b). Although the general level of the relative transmission curve varied, the shape of the curve remained rather constant. Since in all cases the two highest relative transmission coefficients were those for M73 and M93 or for M79 and M93, the maximum of the curve was at M83 or M86. Within the mass ranges M25-M65 and M100-M170, the relative transmission derived from the calibrations in March and April was higher than in the case of the calibrations in July and August. This is due to the changes in the normalized sensitivities for the light compounds (methanol, acetonitrile, acetaldehyde, methacrolein, methyl vinyl ketone, and methyl ethyl ketone) and for $\mathrm{m}$ - and o-xylene.

To survey the performance of our method for determining a relative transmission curve, we compared the normalized sensitivities measured for the compounds considered in the method (Table 2) with the values calculated from Eq. (10) using the relative transmission coefficients derived from the curves. Figure 4 shows that the correlation between the measured and calculated sensitivities is strong. The error, defined as the difference between the calculated and measured value, ranges from -4.5 to $5.7 \mathrm{ncps} \mathrm{ppbv}^{-1}$, the root mean square error is $2.5 \mathrm{ncps} \mathrm{ppbv}^{-1}$, and the maximum relative error is $21 \%$. Since the errors are comparatively small and the data is rather uniformly distributed around the one-to-one line, it seems that our practical method performed quite well. 


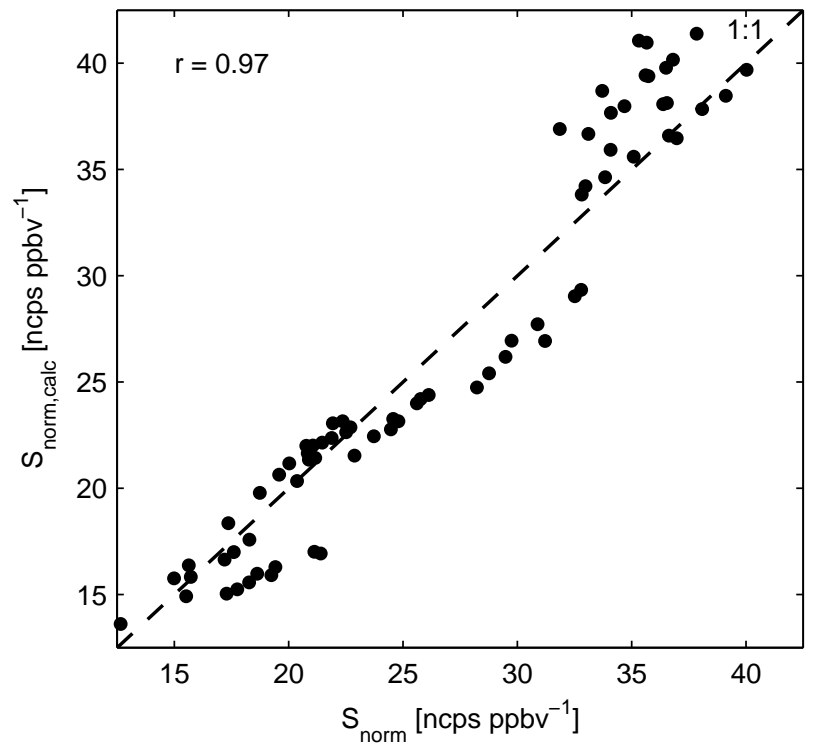

Fig. 4. Comparison of the measured normalized sensitivities with the values calculated from Eq. (10) using the relative transmission coefficients derived from the relative transmission curves. Only the VOCs considered in the determination of the relative transmission curves (Table 2) were included in the comparison. The correlation coefficient is $r=0.97$.

\subsection{Ambient volume mixing ratio measurements}

Figure 5 illustrates the effect of the subtraction of the VOC background signals on the ambient mixing ratio measurements. It shows the hourly averages of the normalized count rates of formaldehyde, methanol, benzene, and monoterpenes (the highest values not visible) during the measurement period 27 March-26 April 2007. The black circles represent the normalized count rates that were calculated according to Eq. (6) and subsequently converted into mixing ratios (see Fig. 6). The grey circles show the normalized count rates when the background signals were not subtracted. The difference between the two normalized count rates was 5.110 ncps for formaldehyde, 45-68 ncps for methanol, $0.082-$ 0.61 ncps for benzene, and $0.071-0.86 \mathrm{ncps}$ for monoterpenes. The medians of the difference were $6.8,60,0.30$, and $0.33 \mathrm{ncps}$, corresponding to mixing ratios of $0.34,2.9$, 0.014 , and 0.039 ppbv, respectively. Since the background signals vary between compounds and over time, they have to be determined frequently for each compound to reduce the bias of PTR-MS measurements and to avoid the presence of false trends in measured mixing ratio time series.

Figure 6 shows the mixing ratios of formaldehyde, methanol, benzene, and monoterpenes measured in the crown space of the Scots pine canopy (at $14 \mathrm{~m}$ above the ground). Air temperature and photosynthetically active radiation were measured above the top of the canopy, at 16.8 and
$18 \mathrm{~m}$, respectively. The hourly averages of the mixing ratios were $0.051-0.57 \mathrm{ppbv}$ for formaldehyde, $0.19-3.1 \mathrm{ppbv}$ for methanol, $0.038-0.39 \mathrm{ppbv}$ for benzene, and $0.020-1.3 \mathrm{ppbv}$ for monoterpenes (the highest mixing ratios not visible). The medians of the hourly averages were $0.17,0.64,0.084$, and $0.068 \mathrm{ppbv}$, respectively. The detection limits for the hourly averages were determined by dividing the detection limits for individual measurements (Table 1) by the square root of the number of individual measurements (25) contributing to the hourly average. The detection limit was $0.020 \mathrm{ppbv}$ for formaldehyde, $0.060 \mathrm{ppbv}$ for methanol, $0.0036 \mathrm{ppbv}$ for benzene, and 0.0092 ppbv for monoterpenes.

The mixing ratios did not have clear diurnal cycles, but in general the maximum values were observed at night. During the warm period on 15 and 16 April, the mixing ratios of formaldehyde, methanol, and monoterpenes were above the average level of the whole month while the mixing ratio of benzene remained at the average level. On the other hand, the mixing ratios of formaldehyde, methanol, and benzene were high at the beginning of the measurement period (27$30 \mathrm{March}$ ) while the rise in the monoterpene mixing ratio was not remarkable. These facts may indicate that monoterpenes had a strong local source, benzene had remote anthropogenic sources, and formaldehyde and methanol had both local and remote sources.

Formaldehyde was not present in our calibration gas standard and we had to determine its relative transmission coefficient (Sect. 2.4.3) to calculate the mixing ratios. Our PTRMS measurements gave slightly lower results than the measurements with a chemical derivatization method at the same site in March-April 2003 (Hellén et al., 2004). Ambient humidity affects the detection of formaldehyde by PTR-MS significantly (e.g. Hansel et al., 1997; Inomata et al., 2008; Wisthaler et al., 2008). The correlation coefficient between the 30-min averages of the ambient water vapour mixing ratio and the hourly averages of the normalized water cluster ion count rate, calculated according to Eq. (6), was 0.99 . We suppose that we could reduce the effect of ambient humidity on the detection of formaldehyde since we took the abundance of the water cluster ions into account when determining the relative transmission coefficient and calculating the mixing ratios. The correlation coefficient between the 30 min averages of the ambient water vapour mixing ratio and the hourly averages of the formaldehyde mixing ratio was only -0.092 . Presumably, the anticorrelation might have been stronger if we had not considered the water cluster ions in the calculation.

The mixing ratios of methanol, benzene, and monoterpenes were calculated using the measured normalized sensitivities and therefore the accuracy was better for these compounds than for formaldehyde. The methanol mixing ratio was somewhat lower than that measured with PTR-MS at the same site in July 2004 (Rinne et al., 2005). This can be partly due to the seasonal variation in the tropospheric chemistry and emissions of methanol, but also the fact that 

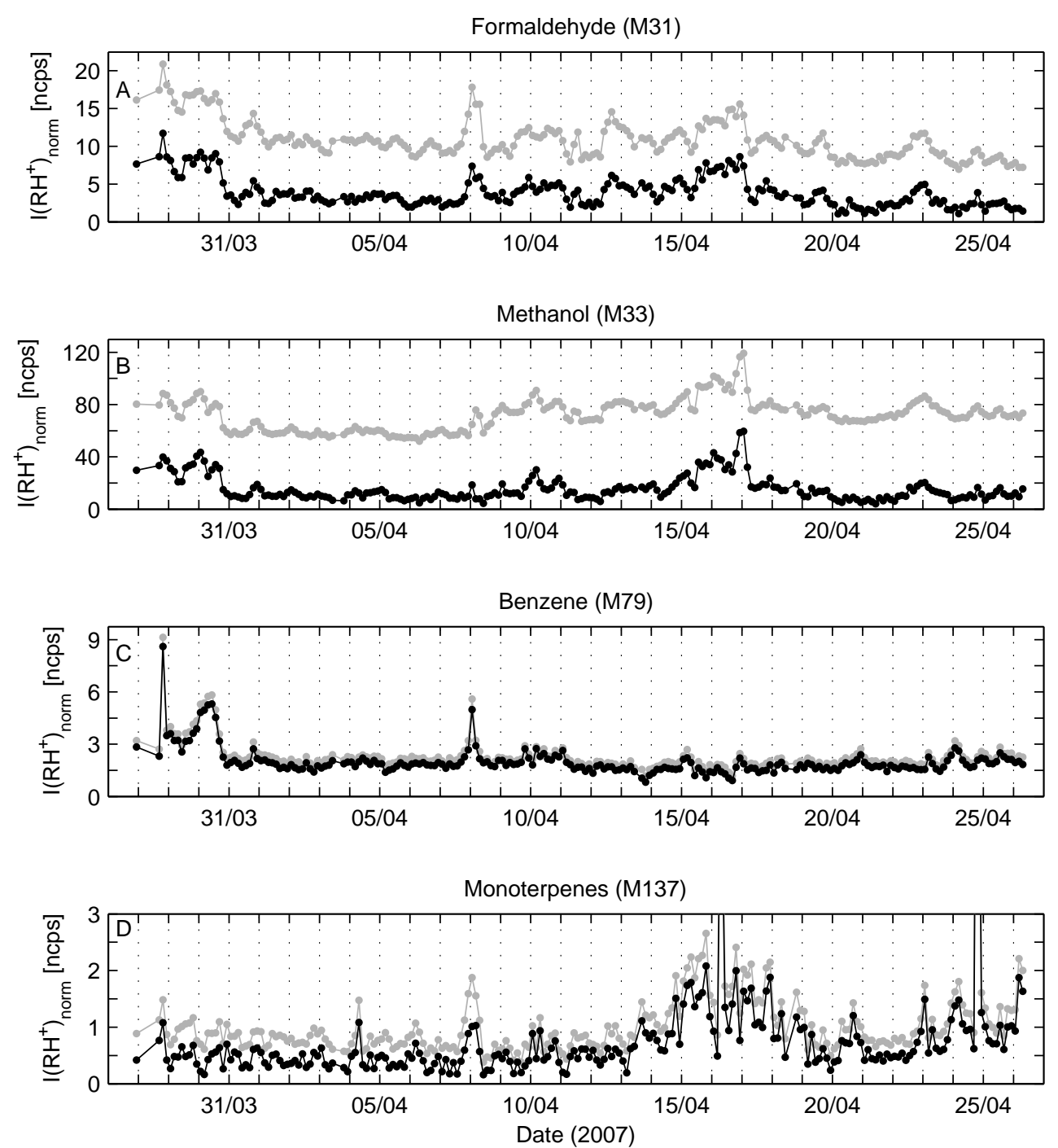

Fig. 5. Hourly averages of the normalized count rates of VOCs during the measurement period 27 March-26 April 2007. The black circles represent the normalized count rates that were calculated according to Eq. (6) and subsequently converted into volume mixing ratios (see Fig. 6). The grey circles show the normalized count rates when the VOC background signals were not subtracted.

the PTR-MS was not calibrated with a gas standard in 2004 can explain the difference. Methanol has not been measured with alternative methods at the SMEAR II station, but the results of the present PTR-MS measurements agree well with the lower limit of the representative mixing ratio range for coniferous and deciduous forests suggested by Heikes et al. (2002). The mixing ratios of benzene and monoterpenes presented in this work are in the same range as the results of gas chromatographic measurements at the same site during the same season (Hakola et al., 2003). Similar monoterpene mixing ratios have been observed also at another boreal forest site in Finland in May (Hakola et al., 2000).

Figure 7 illustrates the relation between the monoterpene mixing ratios derived from the M81 and M137 signals. It shows all individual measurements conducted at the three sampling heights and the corresponding hourly averages. The correlation is stronger for the hourly averages than for the individual measurements. Since the M81 and M137 signals were not measured simultaneously, the differences in the individual measurements are partly due to short-term variations in the monoterpene mixing ratio caused by turbulent eddies. However, the correlation is strong in both data sets, and the slopes and offsets of the straight lines fitted to the data in a least squares sense are close to one and zero, respectively. This indicates that the fragmentation patterns of the major monoterpenes in ambient air were similar to that of $\alpha$-pinene, which was the only monoterpene used in the calibrations, and that there were no major interfering compounds 

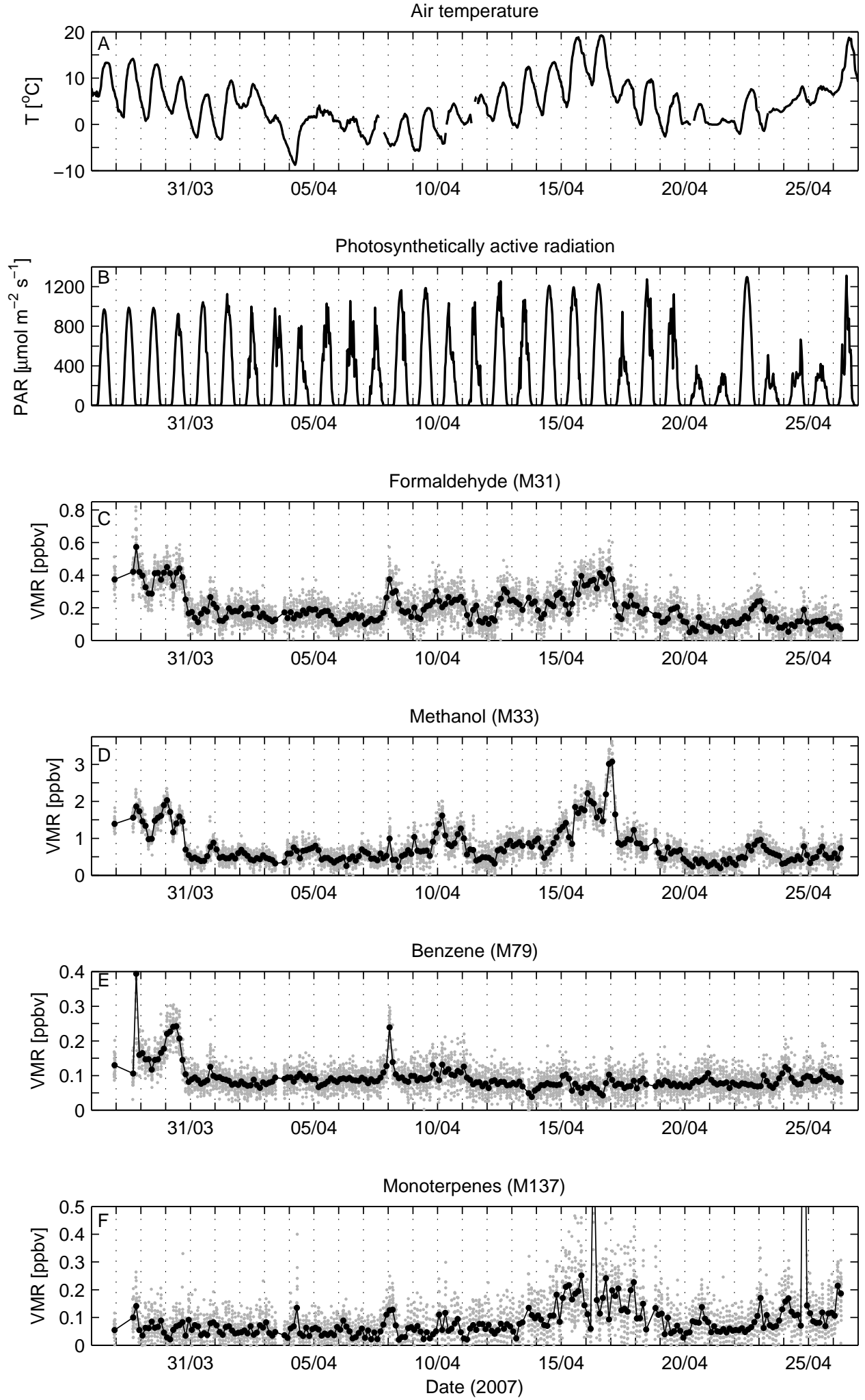

Fig. 6. Air temperature, photosynthetically active radiation, and VOC mixing ratios at the SMEAR II station during the measurement period 27 March-26 April 2007. The grey and black circles represent individual measurements and hourly averages, respectively. 
or fragments detected at M81 and M137. It has been observed that $\alpha$-pinene contributes most to the total monoterpene mixing ratio at the SMEAR II station, but in spring the contributions of $\beta$-pinene and 3-carene are also significant (Hakola et al., 2003). Tani et al. (2003) noticed that the fragmentation patterns of these monoterpenes were quite similar in their PTR-MS and according to Fig. 7 and the results presented by Ruuskanen et al. (2005) that seems to apply to our instrument too. We suppose that the differences between the monoterpene mixing ratios derived from the M81 and M137 signals are due to turbulent eddies, instrumental noise, and minor interfering compounds. However, de Gouw et al. (2003b) and Warneke et al. (2003) observed that the sensitivity of their instrument for $\alpha$-pinene was lower than for $\beta$ pinene and 3-carene. Therefore, it is possible that there was a positive bias in our monoterpene measurements if there were periods when the contributions of $\beta$-pinene and 3-carene to the total monoterpene mixing ratio were enhanced.

\section{Conclusions}

In this paper, we presented our measurement, calibration, and volume mixing ratio calculation methods in detail. These methods have been designed for quantitative long-term field measurements by PTR-MS and are therefore systematic, practical, and as automatic as reasonable. They have proven to be functional and effective in our long-term measurements at the SMEAR II station.

The PTR-MS has to be calibrated regularly with a gas standard to achieve and maintain the accuracy needed in atmospheric VOC measurements. The information obtained from a calibration can be used to determine an instrument specific relative transmission curve, which enables consistent mixing ratio calculation for VOCs not present in a calibration gas standard. The automatic implementation of our method for determining this curve is straightforward, which is an important advantage when the PTR-MS is used for continuous long-term measurements. We illustrated that the relative transmission curves determined with our method were compatible with the relative transmission coefficients derived from the normalized sensitivities measured for the nonfragmenting VOCs in our calibration gas standards. The general level of the relative transmission curve varied according to the changes in the sensitivity, but the shape of the curve remained rather constant. We also proposed a new approach to taking account of the abundance of $\mathrm{H}_{3} \mathrm{O}^{+} \mathrm{H}_{2} \mathrm{O}$ ions in mixing ratio calculation.

The formaldehyde, benzene, and monoterpene mixing ratios measured with PTR-MS were of the same order of magnitude as those measured with other techniques at the same site earlier. The monoterpene mixing ratio derived from the M81 signal corresponded to that derived from the M137 signal. This shows that the fragmentation patterns of the major monoterpenes in ambient air were similar to that of $\alpha$-pinene,
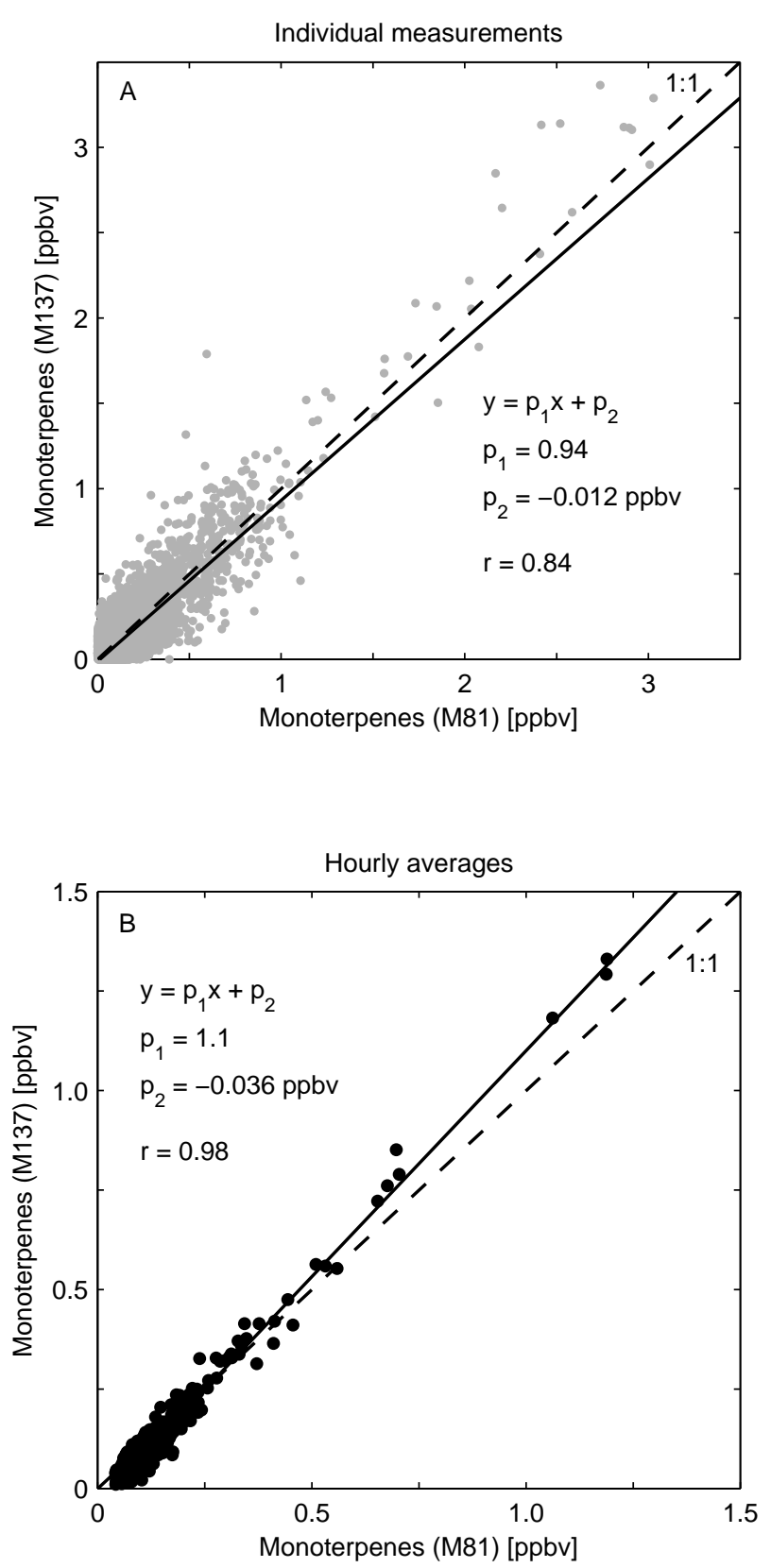

Fig. 7. Relation between the monoterpene mixing ratios derived from the M81 and M137 signals.

the only monoterpene used in the calibrations, and that there were no major interfering compounds detected at M81 and M137. In summary, our volume mixing ratio calculation method gave reasonable results for formaldehyde, which was not present in the calibration gas standards, and naturally also for methanol, benzene, and monoterpenes, which were present in the gas standards. 
Acknowledgements. We thank J. Patokoski and the staff of the SMEAR II station for their assistance in our measurements. We acknowledge the Academy of Finland (projects 120434, 125238, and 209216), the Helsinki University Centre for Environment (Urban and Rural Air Pollution Consortium), and the Kone Foundation for financial support.

Edited by: V.-M. Kerminen

\section{References}

Allan, J. D., Alfarra, M. R., Bower, K. N., Coe, H., Jayne, J. T., Worsnop, D. R., Aalto, P. P., Kulmala, M., Hyötyläinen, T., Cavalli, F., and Laaksonen, A.: Size and composition measurements of background aerosol and new particle growth in a Finnish forest during QUEST 2 using an Aerodyne Aerosol Mass Spectrometer, Atmos. Chem. Phys., 6, 315-327, 2006,

http://www.atmos-chem-phys.net/6/315/2006/.

Ammann, C., Spirig, C., Neftel, A., Steinbacher, M., Komenda, M., and Schaub, A.: Application of PTR-MS for measurements of biogenic VOC in a deciduous forest, Int. J. Mass Spectrom., 239, 87-101, 2004.

Ammann, C., Brunner, A., Spirig, C., and Neftel, A.: Technical note: Water vapour concentration and flux measurements with PTR-MS, Atmos. Chem. Phys., 6, 4643-4651, 2006, http://www.atmos-chem-phys.net/6/4643/2006/.

Andreae, M. O. and Merlet, P.: Emission of trace gases and aerosols from biomass burning, Global Biogeochem. Cy., 15(4), 955-966, 2001.

Atkinson, R. and Arey, J.: Atmospheric degradation of volatile organic compounds, Chem. Rev., 103, 4605-4638, 2003.

Brunner, A., Ammann, C., Neftel, A., and Spirig, C.: Methanol exchange between grassland and the atmosphere, Biogeosciences, 4, 395-410, 2007, http://www.biogeosciences.net/4/395/2007/.

Crutzen, P. J., Williams, J., Pöschl, U., Hoor, P., Fischer, H., Warneke, C., Holzinger, R., Hansel, A., Lindinger, W., Scheeren, B., and Lelieveld, J.: High spatial and temporal resolution measurements of primary organics and their oxidation products over the tropical forests of Surinam, Atmos. Environ., 34, 1161-1165, 2000.

Currie, L. A.: Limits for qualitative detection and quantitative determination - Application to radiochemistry, Anal. Chem., 40(3), 586-593, 1968.

Currie, L. A.: Detection and quantification limits: origins and historical overview, Anal. Chim. Acta, 391, 127-134, 1999.

de Gouw, J. and Warneke, C.: Measurements of volatile organic compounds in the Earth's atmosphere using proton-transferreaction mass spectrometry, Mass Spectrom. Rev., 26, 223-257, 2007.

de Gouw, J., Warneke, C., Karl, T., Eerdekens, G., van der Veen, C., and Fall, R.: Sensitivity and specificity of atmospheric trace gas detection by proton-transfer-reaction mass spectrometry, Int. J. Mass Spectrom., 223-224, 365-382, $2003 \mathrm{a}$.

de Gouw, J., Warneke, C., Holzinger, R., Klüpfel, T., and Williams, J.: Inter-comparison between airborne measurements of methanol, acetonitrile and acetone using two differently configured PTR-MS instruments, Int. J. Mass Spectrom., 239, 129137, 2004. de Gouw, J. A., Goldan, P. D., Warneke, C., Kuster, W. C., Roberts, J. M., Marchewka, M., Bertman, S. B., Pszenny, A. A. P., and Keene, W. C.: Validation of proton transfer reaction-mass spectrometry (PTR-MS) measurements of gas-phase organic compounds in the atmosphere during the New England Air Quality Study (NEAQS) in 2002, J. Geophys. Res., 108(D21), 4682, doi: 10.1029/2003JD003863, 2003b.

Fall, R., Karl, T., Hansel, A., Jordan, A., and Lindinger, W.: Volatile organic compounds emitted after leaf wounding: On-line analysis by proton-transfer-reaction mass spectrometry, J. Geophys. Res., 104(D13), 15 963-15 974, 1999.

Fritsch, F. N. and Carlson, R. E.: Monotone piecewise cubic interpolation, SIAM J. Numer. Anal., 17(2), 238-246, 1980.

Guenther, A., Hewitt, C. N., Erickson, D., Fall, R., Geron, C., Graedel, T., Harley, P., Klinger, L., Lerdau, M., McKay, W. A., Pierce, T., Scholes, B., Steinbrecher, R., Tallamraju, R., Taylor, J., and Zimmerman, P.: A global model of natural volatile organic compound emissions, J. Geophys. Res., 100(D5), 88738892, 1995.

Haapanala, S., Rinne, J., Hakola, H., Hellén, H., Laakso, L., Lihavainen, H., Janson, R., O'Dowd, C., and Kulmala, M.: Boundary layer concentrations and landscape scale emissions of volatile organic compounds in early spring, Atmos. Chem. Phys., 7, 1869-1878, 2007, http://www.atmos-chem-phys.net/7/1869/2007/.

Hakola, H., Laurila, T., Rinne, J., and Puhto, K.: The ambient concentrations of biogenic hydrocarbons at a northern European, boreal site, Atmos. Environ., 34, 4971-4982, 2000.

Hakola, H., Tarvainen, V., Laurila, T., Hiltunen, V., Hellén, H., and Keronen, P.: Seasonal variation of VOC concentrations above a boreal coniferous forest, Atmos. Environ., 37, 1623-1634, 2003.

Hakola, H., Tarvainen, V., Bäck, J., Ranta, H., Bonn, B., Rinne, J., and Kulmala, M.: Seasonal variation of mono- and sesquiterpene emission rates of Scots pine, Biogeosciences, 3, 93-101, 2006, http://www.biogeosciences.net/3/93/2006/.

Hansel, A., Jordan, A., Holzinger, R., Prazeller, P., Vogel, W., and Lindinger, W.: Proton transfer reaction mass spectrometry: online trace gas analysis at the ppb level, Int. J. Mass Spectrom., 149/150, 609-619, 1995.

Hansel, A., Singer, W., Wisthaler, A., Schwarzmann, M., and Lindinger, W.: Energy dependencies of the proton transfer reactions $\mathrm{H}_{3} \mathrm{O}^{+}+\mathrm{CH}_{2} \mathrm{O} \Leftrightarrow \mathrm{CH}_{2} \mathrm{OH}^{+}+\mathrm{H}_{2} \mathrm{O}$, Int. J. Mass Spectrom., 167/168, 697-703, 1997.

Hari, P. and Kulmala, M.: Station for Measuring EcosystemAtmosphere Relations (SMEAR II), Boreal Environ. Res., 10, 315-322, 2005.

Hayward, S., Hewitt, C. N., Sartin, J. H., and Owen, S. M.: Performance characteristics and applications of a proton transfer reaction-mass spectrometer for measuring volatile organic compounds in ambient air, Environ. Sci. Technol., 36, 1554-1560, 2002.

Hayward, S., Tani, A., Owen, S. M., and Hewitt, C. N.: Online analysis of volatile organic compound emissions from Sitka spruce (Picea sitchensis), Tree Physiol., 24, 721-728, 2004.

Heikes, B. G., Chang, W., Pilson, M. E. Q., Swift, E., Singh, H. B., Guenther, A., Jacob, D. J., Field, B. D., Fall, R., Riemer, D., and Brand, L.: Atmospheric methanol budget and ocean implication, Global Biogeochem. Cy., 16(4), 1133, doi:10.1029/ 2002GB001895, 2002. 
Hellén, H., Hakola, H., Reissell, A., and Ruuskanen, T. M.: Carbonyl compounds in boreal coniferous forest air in Hyytiälä, Southern Finland, Atmos. Chem. Phys., 4, 1771-1780, 2004, http://www.atmos-chem-phys.net/4/1771/2004/.

Holzinger, R., Kleiss, B., Donoso, L., and Sanhueza, E.: Aromatic hydrocarbons at urban, sub-urban, rural $\left(8^{\circ} 52^{\prime} \mathrm{N} ; 67^{\circ} 19^{\prime} \mathrm{W}\right)$ and remote sites in Venezuela, Atmos. Environ., 35, 4917-4927, 2001

Inomata, S., Tanimoto, H., Kameyama, S., Tsunogai, U., Irie, H., Kanaya, Y., and Wang, Z.: Technical Note: Determination of formaldehyde mixing ratios in air with PTR-MS: laboratory experiments and field measurements, Atmos. Chem. Phys., 8, 273 284, 2008, http://www.atmos-chem-phys.net/8/273/2008/.

Janson, R. and de Serves, C.: Acetone and monoterpene emissions from the boreal forest in northern Europe, Atmos. Environ., 35, 4629-4637, 2001.

Jiang, M., Marr, L. C., Dunlea, E. J., Herndon, S. C., Jayne, J. T., Kolb, C. E., Knighton, W. B., Rogers, T. M., Zavala, M., Molina, L. T., and Molina, M. J.: Vehicle fleet emissions of black carbon, polycyclic aromatic hydrocarbons, and other pollutants measured by a mobile laboratory in Mexico City, Atmos. Chem. Phys., 5, 3377-3387, 2005, http://www.atmos-chem-phys.net/5/3377/2005/.

Karl, T., Guenther, A., Jordan, A., Fall, R., and Lindinger, W.: Eddy covariance measurement of biogenic oxygenated VOC emissions from hay harvesting, Atmos. Environ., 35, 491-495, 2001.

Karl, T., Curtis, A. J., Rosenstiel, T. N., Monson, R. K., and Fall, R.: Transient releases of acetaldehyde from tree leaves - products of a pyruvate overflow mechanism?, Plant Cell Environ., 25, 11211131, 2002a.

Karl, T., Hansel, A., Märk, T., Lindinger, W., and Hoffmann, D.: Trace gas monitoring at the Mauna Loa Baseline Observatory using Proton-Transfer Reaction Mass Spectrometry, Int. J. Mass Spectrom., 223-224, 527-538, 2003a.

Karl, T., Jobson, T., Kuster, W. C., Williams, E., Stutz, J., Shetter, R., Hall, S. R., Goldan, P., Fehsenfeld, F., and Lindinger, W.: Use of proton-transfer-reaction mass spectrometry to characterize volatile organic compound sources at the La Porte super site during the Texas Air Quality Study 2000, J. Geophys. Res., 108(D16), 4508, doi:10.1029/2002JD003333, 2003 b.

Karl, T. G., Spirig, C., Rinne, J., Stroud, C., Prevost, P., Greenberg, J., Fall, R., and Guenther, A.: Virtual disjunct eddy covariance measurements of organic compound fluxes from a subalpine forest using proton transfer reaction mass spectrometry, Atmos. Chem. Phys., 2, 279-291, 2002b.

Kulmala, M., Hämeri, K., Aalto, P. P., Mäkelä, J. M., Pirjola, L., Nilsson, E. D., Buzorius, G., Rannik, Ü., Dal Maso, M., Seidl, W., Hoffman, T., Janson, R., Hansson, H.-C., Viisanen, Y., Laaksonen, A., and O'Dowd, C. D.: Overview of the international project on biogenic aerosol formation in the boreal forest (BIOFOR), Tellus, 53B, 324-343, 2001.

Kulmala, M., Suni, T., Lehtinen, K. E. J., Dal Maso, M., Boy, M., Reissell, A., Rannik, Ü., Aalto, P., Keronen, P., Hakola, H., Bäck, J., Hoffmann, T., Vesala, T., and Hari, P.: A new feedback mechanism linking forests, aerosols, and climate, Atmos. Chem. Phys., 4, 557-562, 2004, http://www.atmos-chem-phys.net/4/557/2004/.

Lee, A., Goldstein, A. H., Keywood, M. D., Gao, S., Varutbangkul, V., Bahreini, R., Ng, N. L., Flagan, R. C., and Se- infeld, J. H.: Gas-phase products and secondary aerosol yields from the ozonolysis of ten different terpenes, J. Geophys. Res., 111, D07302, doi:10.1029/2005JD006437, 2006a.

Lee, A., Goldstein, A. H., Kroll, J. H., Ng, N. L., Varutbangkul, V., Flagan, R. C., and Seinfeld, J. H.: Gas-phase products and secondary aerosol yields from the photooxidation of 16 different terpenes, J. Geophys. Res., 111, D17305, doi:10.1029/ 2006JD007050, 2006b.

Lindinger, W., Hansel, A., and Jordan, A.: On-line monitoring of volatile organic compounds at pptv levels by means of ProtonTransfer-Reaction Mass Spectrometry (PTR-MS) - Medical applications, food control and environmental research, Int. J. Mass Spectrom., 173, 191-241, 1998a.

Lindinger, W., Hansel, A., and Jordan, A.: Proton-transfer-reaction mass spectrometry (PTR-MS): on-line monitoring of volatile organic compounds at pptv levels, Chem. Soc. Rev., 27, 347-354, 1998b.

Nozière, B. and Esteve, W.: Organic reactions increasing the absorption index of atmospheric sulfuric acid aerosols, Geophys. Res. Lett., 32, L03812, doi:10.1029/2004GL021942, 2005.

Paulsen, D., Dommen, J., Kalberer, M., Prévôt, A. S. H., Richter, R., Sax, M., Steinbacher, M., Weingartner, E., and Baltensperger, U.: Secondary organic aerosol formation by irradiation of 1,3,5trimethylbenzene- $\mathrm{NO}_{\mathrm{x}}-\mathrm{H}_{2} \mathrm{O}$ in a new reaction chamber for atmospheric chemistry and physics, Environ. Sci. Technol., 39, 2668-2678, 2005.

Piccot, S. D., Watson, J. J., and Jones, J. W.: A global inventory of volatile organic compound emissions from anthropogenic sources, J. Geophys. Res., 97(D9), 9897-9912, 1992.

Rinne, H. J. I., Guenther, A. B., Warneke, C., de Gouw, J. A., and Luxembourg, S. L.: Disjunct eddy covariance technique for trace gas flux measurements, Geophys. Res. Lett., 28(16), 3139-3142, 2001.

Rinne, J., Hakola, H., Laurila, T., and Rannik, Ü.: Canopy scale monoterpene emissions of Pinus sylvestris dominated forests, Atmos. Environ., 34, 1099-1107, 2000.

Rinne, J., Ruuskanen, T. M., Reissell, A., Taipale, R., Hakola, H., and Kulmala, M.: On-line PTR-MS measurements of atmospheric concentrations of volatile organic compounds in a European boreal forest ecosystem, Boreal Environ. Res., 10, 425-436, 2005.

Rinne, J., Taipale, R., Markkanen, T., Ruuskanen, T. M., Hellén, H., Kajos, M. K., Vesala, T., and Kulmala, M.: Hydrocarbon fluxes above a Scots pine forest canopy: measurements and modeling, Atmos. Chem. Phys., 7, 3361-3372, 2007, http://www.atmos-chem-phys.net/7/3361/2007/.

Ruuskanen, T. M., Kolari, P., Bäck, J., Kulmala, M., Rinne, J., Hakola, H., Taipale, R., Raivonen, M., Altimir, N., and Hari, P.: On-line field measurements of monoterpene emissions from Scots pine by proton-transfer-reaction mass spectrometry, Boreal Environ. Res., 10, 553-567, 2005.

Ruuskanen, T. M., Taipale, R., Rinne, J., Kajos, M. K., Hakola, H., and Kulmala, M.: Quantitative long-term measurements of VOC concentrations by PTR-MS: Annual cycle at a boreal forest site, Atmos. Chem. Phys. Discuss., accepted, 2008.

Spirig, C., Neftel, A., Ammann, C., Dommen, J., Grabmer, W., Thielmann, A., Schaub, A., Beauchamp, J., Wisthaler, A., and Hansel, A.: Eddy covariance flux measurements of biogenic VOCs during ECHO 2003 using proton transfer reaction mass 
spectrometry, Atmos. Chem. Phys., 5, 465-481, 2005, http://www.atmos-chem-phys.net/5/465/2005/.

Steinbacher, M., Dommen, J., Ammann, C., Spirig, C., Neftel, A., and Prevot, A. S. H.: Performance characteristics of a protontransfer-reaction mass spectrometer (PTR-MS) derived from laboratory and field measurements, Int. J. Mass Spectrom., 239, 117-128, 2004.

Tani, A., Hayward, S., and Hewitt, C. N.: Measurement of monoterpenes and related compounds by proton transfer reaction-mass spectrometry (PTR-MS), Int. J. Mass Spectrom., 223-224, 561578, 2003.

Tani, A., Hayward, S., Hansel, A., and Hewitt, C. N.: Effect of water vapour pressure on monoterpene measurements using proton transfer reaction-mass spectrometry (PTR-MS), Int. J. Mass Spectrom., 239, 161-169, 2004.

Tarvainen, V., Hakola, H., Hellén, H., Bäck, J., Hari, P., and Kulmala, M.: Temperature and light dependence of the VOC emissions of Scots pine, Atmos. Chem. Phys., 5, 989-998, 2005, http://www.atmos-chem-phys.net/5/989/2005/.

Tunved, P., Hansson, H.-C., Kerminen, V.-M., Ström, J., Dal Maso, M., Lihavainen, H., Viisanen, Y., Aalto, P. P., Komppula, M., and Kulmala, M.: High natural aerosol loading over boreal forests, Science, 312, 261-263, 2006.

Vartiainen, E., Kulmala, M., Ruuskanen, T. M., Taipale, R., Rinne, J., and Vehkamäki, H.: Formation and growth of indoor air aerosol particles as a result of D-limonene oxidation, Atmos. Environ., 40, 7882-7892, 2006.

Vesala, T., Haataja, J., Aalto, P., Altimir, N., Buzorius, G., Garam, E., Hämeri, K., Ilvesniemi, H., Jokinen, V., Keronen, P., Lahti, T., Markkanen, T., Mäkelä, J. M., Nikinmaa, E., Palmroth, S., Palva, L., Pohja, T., Pumpanen, J., Rannik, Ü., Siivola, E., Ylitalo, H., Hari, P., and Kulmala, M.: Long-term field measurements of atmosphere-surface interactions in boreal forest combining forest ecology, micrometeorology, aerosol physics and atmospheric chemistry, Trends in Heat, Mass and Momentum Transfer, 4, 1735, 1998 .

Warneke, C., van der Veen, C., Luxembourg, S., de Gouw, J. A., and Kok, A.: Measurements of benzene and toluene in ambient air using proton-transfer-reaction mass spectrometry: calibration, humidity dependence, and field intercomparison, Int. J. Mass Spectrom., 207, 167-182, 2001.
Warneke, C., Luxembourg, S. L., de Gouw, J. A., Rinne, H. J. I., Guenther, A. B., and Fall, R.: Disjunct eddy covariance measurements of oxygenated volatile organic compounds fluxes from an alfalfa field before and after cutting, J. Geophys. Res., 107(D8), 4067, doi:10.1029/2001JD000594, 2002.

Warneke, C., de Gouw, J. A., Kuster, W. C., Goldan, P. D., and Fall, R.: Validation of atmospheric VOC measurements by proton-transfer-reaction mass spectrometry using a gaschromatographic preseparation method, Environ. Sci. Technol., 37, 2494-2501, 2003.

Warneke, C., de Gouw, J. A., Stohl, A., Cooper, O. R., Goldan, P. D., Kuster, W. C., Holloway, J. S., Williams, E. J., Lerner, B. M., McKeen, S. A., Trainer, M., Fehsenfeld, F. C., Atlas, E. L., Donnelly, S. G., Stroud, V., Lueb, A., and Kato, S.: Biomass burning and anthropogenic sources of CO over New England in the summer 2004, J. Geophys. Res., 111, D23S15, doi:10.1029/ 2005JD006878, 2006.

Wisthaler, A., Jensen, N. R., Winterhalter, R., Lindinger, W., and Hjorth, J.: Measurements of acetone and other gas phase product yields from the $\mathrm{OH}$-initiated oxidation of terpenes by protontransfer-reaction mass spectrometry (PTR-MS), Atmos. Environ., 35, 6181-6191, 2001.

Wisthaler, A., Hansel, A., Dickerson, R. R., and Crutzen, P. J.: Organic trace gas measurements by PTR-MS during INDOEX 1999, J. Geophys. Res., 107(D19), 8024, doi:10.1029/ 2001JD000576, 2002.

Wisthaler, A., Apel, E. C., Bossmeyer, J., Hansel, A., Junkermann, W., Koppmann, R., Meier, R., Müller, K., Solomon, S. J., Steinbrecher, R., Tillmann, R., and Brauers, T.: Technical Note: Intercomparison of formaldehyde measurements at the atmosphere simulation chamber SAPHIR, Atmos. Chem. Phys., 8, 21892200, 2008, http://www.atmos-chem-phys.net/8/2189/2008/.

Zhao, J. and Zhang, R.: Proton transfer reaction rate constants between hydronium ion $\left(\mathrm{H}_{3} \mathrm{O}^{+}\right)$and volatile organic compounds, Atmos. Environ., 38, 2177-2185, 2004. 